\title{
Defending Union Values in Judicial \\ Proceedings. On How to Turn Article 2 TEU \\ into a Judicially Applicable Provision
}

\author{
Luke Dimitrios Spieker
}

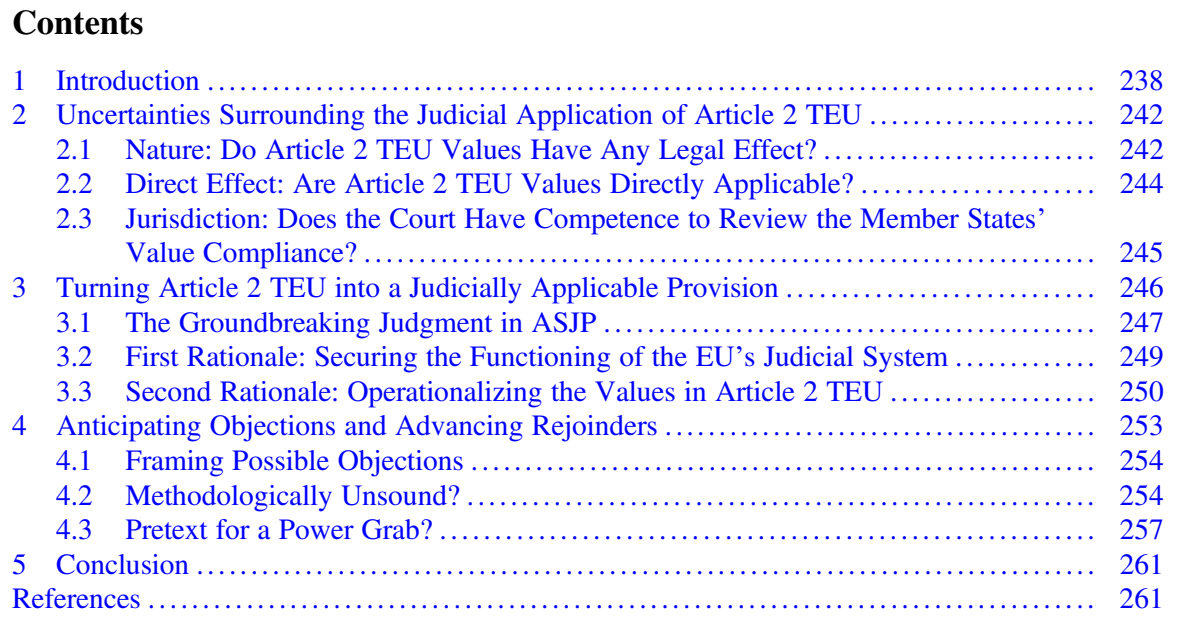

\begin{abstract}
This chapter centres on the question of how to address violations of EU values in judicial proceedings before the Court of Justice. Instead of relying on fundamental freedoms, EU secondary legislation or the Charter, this chapter explores a more promising path-engaging with Article 2 TEU itself. Yet this path rests on a crucial premise: the judicial applicability of the values enshrined in Article 2 TEU. Such a judicial applicability is far from self-evident and needs to be carefully construed. Based on recent jurisprudential developments, this chapter will propose ways to operationalise Article 2 TEU without curtailing its unrestricted scope of application. The judgments of Associação Sindical dos Juizes Portugueses,
\end{abstract}

This chapter draws on Spieker (2019a) and von Bogdandy and Spieker (2019).

\section{D. Spieker $(\bowtie)$}

Max Planck Institute for Comparative Public Law and International Law, Heidelberg, Germany e-mail: spieker@mpil.de 
Minister for Justice and Equality (L.M.) and Commission v. Poland will be at the heart of this contribution.

\section{Introduction}

As evidenced by many contributions in this volume, ${ }^{1}$ the developments in several EU Member States have consolidated to a larger illiberal turn posing a systemic threat to the values enshrined in Article 2 TEU. Especially the governing parties in Poland and Hungary started rejecting the model of a liberal democracy and attacking checks and balances of the political process. Much has been written on whether the Union should $\mathrm{act}^{2}$ and if so, how to institutionally and procedurally address these issues. ${ }^{3}$ Yet one thing seems almost certain: any path requiring unanimity in the Council (Article 7 TEU) or a Treaty change ${ }^{4}$ seems to be a political pipe dream. Since backsliding Member States will be watching each other's backs, these paths are barred. ${ }^{5}$

This political petrification reminds a well-known pattern of European integration: In times, when the necessary actions were not pursued in the realm of politics, the CJEU stepped in as an 'engine of integration' to safeguard the European integration agenda. ${ }^{6}$ In the late $1960 \mathrm{~s}$, it was the Court that compensated the political stagnation with its constitutionalizing jurisprudence. ${ }^{7}$ In the face of a growing legitimacy deficit on the Community level, it was the Court that developed fundamental rights as general principles. ${ }^{8}$ And when facing the political inertia in constructing the internal market, it was the Court that stepped in with its doctrine of mutual recognition. ${ }^{9}$

\footnotetext{
${ }^{1}$ See e.g. the contributions of Beata Bakó and Marcin Wiącek in this volume.

${ }^{2}$ On the EU's mandate and legitimacy to intervene, see von Bogdandy (2020), pp. 711-715; Maduro and Menezes Queiroz (2020), pp. 370-371; Iliopoulou-Penot (2019); Hillion (2016), pp. 60-64; Closa (2016), pp. 15-22. Critically with regard to the Union's own democracy and justice deficits, see among many others Weiler (2016a).

${ }^{3}$ For a comprehensive assessment, see the individual contributions to Jakab and Kochenov (2017), Closa and Kochenov (2016a) and Schroeder (2016a). See further Möllers and Schneider (2018), Skouris (2018), Waelbroeck and Oliver (2017), Pech et al. (2016) and Schorkopf (2016).

${ }^{4}$ For an amendment of Art. 7 TEU or 51(1) CFR, see e.g. Reding (2013).

${ }^{5}$ See e.g. Orbán (2017): 'a campaign of inquisition against Poland will never succeed, because Hungary will resort to all the legal mechanisms offered by the European Union in order to show its solidarity with the Polish people.'

${ }^{6}$ Lenaerts (1992), pp. 2, 10 et seq. See already Pescatore (1974), p. 89; Lecourt (1976), pp. 306 et seq. Critically, Rasmussen (1986), p. 61.

${ }^{7}$ CJEU, Case C-26/62 Van Gend en Loos, ECLI:EU:C:1963:1; Case C-6/64 Costa/E.N.E.L., ECLI: EU:C:1964:66; Mancini (1989), p. 612.

${ }^{8}$ CJEU, Case C-29/69 Stauder, ECLI:EU:C:1969:57, para. 7; Case C-11/70 Internationale Handelsgesellschaft, ECLI:EU:C:1970:114, para. 4; de Búrca (2011), pp. 475 et seq.

${ }^{9}$ CJEU, Case C-120/78 Rewe, ECLI:EU:C:1979:42; Pescatore (2008).
} 
When it comes to countering the illiberal turn in several Member States, a similar inertia seems to beset the political plane and especially the Council as the key decision maker under the Article 7 TEU procedure. Therefore, many argued to concentrate on judicial mechanisms, to employ the infringement procedure under Article 258 TFEU $^{10}$ or to interact with brave national courts via the preliminary reference procedure (Article 267 TFEU). ${ }^{11}$

Although it might place an immense burden on the Court's legitimacy, ${ }^{12}$ there are solid arguments for involving the Court of Justice. First, the appearance of legality is crucial for governments in backsliding Member States. ${ }^{13}$ Since the CJEU enjoys considerable trust from both national courts and the public, ${ }^{14}$ an authoritative judgment declaring the attacks on domestic checks and balances illegal would constitute a severe set-back. Further, any non-compliance with these judgments would not only damage the façade of legality but lead to a new stage of escalation. ${ }^{15}$ Second, governments in backsliding Member States try to shift the debate on their value-compliance into the sphere of moral and ideological convictions. Such conflicts can easily turn heated and trigger antagonism or polarisation. ${ }^{16}$ Judicial procedures may help shifting the discourse to legal principles and thus into more rational channels. Third, a frequent objection of backsliding Member States is that the European Commission is ideologically biased seeking to force its own conception of the Union's common values on the Member States. ${ }^{17}$ Being a court, the CJEU might seem more neutral than the 'politicized' Commission. As some observed in the context of the Euro-crisis, procedures before the Court have the potential to depoliticize conflicts and unfold an integrating potential. ${ }^{18}$ Finally, the political Article 7 TEU procedure reveals severe shortcomings with regard to procedural

\footnotetext{
${ }^{10}$ See e.g. Schmidt and Bogdanowicz (2018), pp. 1073-1080; Scheppele (2016). Critically, see Kochenov and Bárd (2019), pp. 264 et seq.

${ }^{11}$ See e.g. Blauberger and Kelemen (2017), pp. 325-326. See already von Bogdandy et al. (2012).

${ }^{12}$ Möllers and Schneider (2018), pp. 107, 147; Blauberger and Kelemen (2017), p. 331.

${ }^{13}$ See e.g. Jakab (2020), pp. 12 et seq. See further Scheppele (2018), Bernatt and Ziółkowski (2018) and Landau (2013).

${ }^{14}$ In 2012, the CJEU was 'the only European institution that is trusted by a majority', see European Commission, Standard Eurobarometer 78 (Autumn 2012), p. 73 (after 2012, the Eurobarometer does not include data specifically on trust in the CJEU anymore). On the trust of national judges in the CJEU, see Mayoral (2016).

${ }^{15}$ On the general Member State compliance with CJEU decisions and the very limited number of Article 260(2) TFEU procedures, see e.g. European Commission, Monitoring the Application of Union Law, 2018 Annual Report, Part I: General statistical overview, p. 22. Critically with regard to the reliability of this data, see e.g. Falkner (2018).

${ }^{16}$ See von Bogdandy's contribution in this volume.

${ }^{17}$ See e.g. Press Release, 'They want to make Soros's man the President of the Commission' (2 July 2019), www.miniszterelnok.hu/they-want-to-make-soross-man-the-president-of-the-commission/. See also Mendelski (2016).

${ }^{18}$ Krenn and Farahat (2018). Cautious, see Everling (2015). On the depoliticising potential of court proceedings more generally, see Sunstein (1999), pp. 24 et seq.; Möllers (2013), pp. 92 et seq., 96 et seq. as well as Easton (1965), pp. 262, 264; Luhmann (1989), pp. 121 et seq.
} 
guarantees. ${ }^{19}$ As emphasised by Armin von Bogdandy, however, the fairness of European responses is of essence. ${ }^{20}$ Such fairness is assured in CJEU procedures by granting the defendant Member State a full set of procedural rights and guarantees.

So far, jurisprudential solutions seem to have proven successful, as the Polish example demonstrates. Many Polish courts submitted references concerning the Polish reforms curtailing the judiciary. ${ }^{21}$ Further, the Commission successfully launched several infringement procedures. ${ }^{22}$ Already after the Court ordered interim measures, ${ }^{23}$ the Polish government reversed some parts of its reforms. ${ }^{24}$ This shows that even governments in backsliding Member States remain responsive to CJEU decisions.

This leads to the following question, which will be at the heart of this chapter: What happens when a case, in which Union values are at stake, reaches the CJEU? What substantive provisions can be invoked? The preliminary problem is that important parts of the Polish or Hungarian reforms seem to escape the scope of EU law. As such, provisions of the EU acquis, like fundamental freedoms or

\footnotetext{
${ }^{19}$ See e.g. Niedobitek (2018), p. 241.

${ }^{20}$ See von Bogdandy's contribution in this volume.

${ }^{21}$ See e.g. A. K. (Indépendance de la chambre disciplinaire de la Cour suprême) (Joined Cases C-585/18, C-624/18 and C-625/18) and Miasto Lowicz (Joined Cases C-558/18 and C-563/18). See also the references by the Polish Supreme Court in W.Ż. (Case C-487/19), Prokurator Generalny (Case C-508/19) and Getin Noble Bank (Case C-132/20), by district courts in Prokuratura Rejonowa w Stubicach (Case C-623/18) and Prokuratura Rejonowa w Mińsku Mazowieckim (Joined Cases C-748/19 to C-754/19), by the Polish Supreme Administrative Court in A.B. u.a. (Nomination des juges à la Cour suprême-Recours) (Case C-824/18) and by the Disciplinary Court of the Bar Association (Warsaw) in Ministerstwo Sprawiedliwości (Case C-55/20). See further the preliminary references concerning judicial independence by a Hungarian Court in $I S$ (Case C-564/19) and by Romanian courts in Asociația "Forumul Judecătorilor Din România" (Joined Cases C-83/19, C-127/19 and C-195/19), SO (Case C-291/19), Asociația "Forumul Judecătorilor din România" (Case C-355/19), DNA- Serviciul Teritorial Oradea (Case C-379/ 19), Statul Român-Ministerul Finanțelor Publice (Case C-397/19), Asociația "Forumul Judecătorilor din România" (Case C-547/19), Ministerul Public (Case C-811/19). Finally, there are references from a German Court in Land Hessen (Case C-272/19) and a Maltese court in Repubblika (Case C-896/19).

${ }^{22}$ See CJEU, Case C-619/18 Commission v. Poland (Indépendance de la Cour suprême), ECLI:EU: C:2019:531; Case C-192/18 Commission v. Poland (Indépendance des juridictions de droit commun), ECLI:EU:C:2019:924. Another procedure has been initiated against the disciplinary regime for judges, see Commission v. Poland, Case C-791/19. Further, infringement proceedings were successfully initiated against the Hungarian foreign-NGO and higher-education laws, see CJEU, Case C-66/18 Commission v. Hungary (Enseignement supérieur), ECLI:EU: C:2020:792; Case C-78/18 Commission v. Hungary (Transparency of associations), ECLI:EU: C:2020:476.

${ }^{23}$ CJEU, Order of 19 October 2018 (ECLI:EU:C:2018:852) and 17 December 2018 (ECLI:EU: C:2018:1021) in Commission v. Poland (Indépendance de la Cour suprême), supra note 22.

${ }^{24}$ On 21 November 2018 the Polish Sejm passed an act reinstating the previous retirement age for judges, see the Press Release (17 December 2018), see www.president.pl/en/news/art,926, president-signs-bill-amending-law-on-supreme-court.html.
} 
secondary legislation, cannot capture these measures. ${ }^{25}$ And even if some developments might fall within the scope of these provisions, the infringement procedures against Hungary illustrate that relying on them can lead to superficial, eventually unsuccessful results. ${ }^{26}$ The scope of the Charter of Fundamental Rights (CFR) is equally limited. On one hand, the Charter's applicability to Member State actions is limited to 'situations ... within the scope of European Union law'. ${ }^{27}$ This excludes purely internal situations, areas of not actually exercised EU competences ${ }^{28}$ and purely hypothetical links. ${ }^{29}$ On the other hand, threats to democracy and the rule of law are not always depictable as fundamental rights violations. Though being essentially interrelated, ${ }^{30}$ democracy and the rule of law go beyond the protection of fundamental rights and include structural or institutional elements that affect the organization of State. ${ }^{31}$ So what is the alternative?

Taking up the latest jurisprudential developments, this chapter explores a more promising path: relying on Article 2 TEU itself. That provision states at a prominent position: 'The Union is founded on the values of respect for human dignity, freedom, democracy, equality, the rule of law and respect for human rights ... These values are common to the Member States ...'. Article 2 TEU presents two features qualifying it especially for countering the illiberal tendencies in EU Member States. First, it has an unrestricted scope of application-it applies to any Member State act irrespective of any link to (other) EU law. ${ }^{32}$ Second, it is not confined to ensuring

\footnotetext{
${ }^{25}$ For examples of how these developments can still be addressed under fundamental freedoms and secondary legislation, see the grounds on which the Commission based its infringement procedures against Hungary, supra note 22. For a further discussion of this path, see e.g. Dawson and Muir (2013).

${ }^{26}$ CJEU, Case C-286/12 Commission v. Hungary, ECLI:EU:C:2012:687. See further Halmai (2017).

${ }^{27}$ CJEU, Case C-617/10 Åkerberg Fransson, ECLI:EU:C:2013:105, paras. 18 et seq. For attempts to systematise the post-Fransson case law, see e.g. Lazzerini (2018), pp. 183 et seq.; Safjan et al. (2016); Spaventa (2016). Many argue that the Charter's scope can only be triggered by a specific provision of EU law actually applying in the case at hand, see e.g. Borowsky (2014), para. 30b; Safjan (2014), pp. 4 et seq.; Sarmiento (2013), p. 1279; Ladenburger (2012), p. 163; Rosas (2012), p. 1284.

${ }^{28}$ CJEU, Case C-370/12 Pringle, ECLI:EU:C:2012:756, paras. 180-181; Case C-198/13 Hernández, ECLI:EU:C:2014:2055, para. 36.

${ }^{29}$ CJEU, Case C-299/95 Kremzow, ECLI:EU:C:1997:254, para. 16; Case C-40/11 Iida, ECLI:EU: C:2012:691, para. 77.

${ }^{30}$ Habermas (2005). See further Carrera et al. (2013), p. 30.

${ }^{31}$ EU Fundamental Rights Agency (2014), p. 10.

${ }^{32}$ See in rare agreement European Commission, A new EU Framework to strengthen the Rule of Law, $\operatorname{COM}(2014) 158$, p. 5 and Council of the European Union, Opinion of the Legal Service: Commission's Communication on a new EU Framework to strengthen the Rule of Law: compatibility with the Treaties, 10296/14, para. 17. See further European Commission, Communication on Art. 7 of the Treaty on European Union (15 October 2003), COM(2003) 606 final, p. 5; European Convention, Praesidium: Presentation of an initial draft set of Articles of Part I of the Constitutional Treaty, CONV 528/03, p. 11; Klamert and Kochenov (2019), p. 25; Hilf and Schorkopf (2020), para. 18; Calliess (2016), para. 10.
} 
'respect for human rights', but also threats to democracy and the rule of law in their structural, institutional dimension.

Yet this path rests on a central premise: the judicial applicability of the values enshrined in Article 2 TEU. This applicability, however, is far from self-evident and needs to be carefully construed. While much has been written on the Union's common values, ${ }^{33}$ their position in EU law and how they feature in the CJEU's jurisprudence, ${ }^{34}$ there still remains a plethora of uncertainties. As such, this chapter will first address uncertainties related to the values' legal nature, their direct effect and the jurisdiction of the Court (Sect. 2). Based on the CJEU's recent jurisprudence, this contribution will then propose ways to operationalise Article 2 TEU without curtailing its unrestricted scope of application (Sect. 3). The judgments of Associação Sindical dos Juízes Portugueses (ASJP), ${ }^{35}$ Minister for Justice and Equality (L.M.), ${ }^{36}$ and Commission v. Poland ${ }^{37}$ will be at the heart of this analysis. Placing an activated Article 2 TEU in the hands of Luxembourg will most certainly raise doubts and criticism. Therefore, this chapter will close by anticipating likely objections and advancing possible rejoinders (Sect. 4).

\section{Uncertainties Surrounding the Judicial Application of Article 2 TEU}

Before engaging with the most recent case law, it seems worthwhile to analyse the uncertainties and potential shortcomings that might prevent a judicial application of Article 2 TEU. These uncertainties can be narrowed down to three key points: Its nature (Sect. 2.1), direct effect (Sect. 2.2), and the jurisdiction of the CJEU (Sect. $2.3)$.

\subsection{Nature: Do Article 2 TEU Values Have Any Legal Effect?}

Scott Shapiro once wrote that 'there is often no way to resolve specific disagreements about the law without first resolving disagreements about the nature of law'. ${ }^{38}$ This holds especially true for an overarching provision like Article 2 TEU. By using the term 'value', the Treaty drafters introduced a rather ambiguous notion into EU

\footnotetext{
${ }^{33}$ See among many others Schorkopf (2020), Levits (2018a), Voßkuhle (2017), Kochenov (2017a), Weiler (2016b), von Bogdandy (2010), Calliess (2009) and Williams (2009).

${ }^{34}$ See e.g. Rossi (2020), Cannizzaro (2018), Baratta (2018), Lenaerts (2017a) and Nicolosi (2015).

${ }^{35}$ CJEU, Case C-64/16 Associação Sindical dos Juízes Portugueses, ECLI:EU:C:2018:117.

${ }^{36}$ CJEU, Case C-216/18 PPU Minister for Justice and Equality, ECLI:EU:C:2018:586.

${ }^{37} \mathrm{CJEU}$, Commission v. Poland (Indépendance de la Cour suprême), supra note 22.

${ }^{38}$ Shapiro (2011), p. 28.
} 
primary law. ${ }^{39}$ Values are widely used in very different contexts: law, politics, economics, philosophy, ethics, religion, sociology, psychology ... Values are very close to what Uwe Pörsken called 'plastic words' ${ }^{40}$ - empty formulas that mean everything and nothing. As context-dependent shapeshifters, they can be used in different fields with different meanings.

In law, values are generally juxtaposed with 'principles' and 'rules' ${ }^{41}$ and in the Treaties especially with 'competences' and 'objectives'. ${ }^{42}$ Yet values somehow transcend these dichotomies without revealing their precise character. One might justifiably ask why the drafters burdened the Treaties with such a can of worms. Unfortunately, analysing the European Convention's travaux is of no further use. Although several members saw the uncertainties tied to values and suggested replacing them with principles, ${ }^{43}$ the term remained in the draft without being grounded in a solid theory of what they were supposed to be. ${ }^{44}$

As such, it is not self-evident that Article 2 TEU values unfold legal effects. Some even doubt their status as law. ${ }^{45}$ Such doubts, however, are hardly convincing. The values of Article 2 TEU are laid down in the operative part of a legal text. They are applied in legally determined procedures by public institutions (Article 7 and 49 (1) TEU) and their disregard leads to sanctions, which are of legal nature. ${ }^{46}$ In fact,

\footnotetext{
${ }^{39}$ See already draft Art. I-2 of the Constitution of Europe. Before the Constitution, the term 'principles' was used, see Art. 6(1) TEU-Nice, Art. F(1) TEU-Maastricht. See however the reference to 'values' in the context of the Austria crisis, Martti Ahtisaari, Jochen Frowein and Marcelino Oreja, Report of 8 September 2000, paras. 115, 117 and of EU enlargement, see e.g. Declaration on European Identity (Copenhagen, Dec. 14, 1973), 1973 Bull. EC 12/118.

${ }^{40}$ See Pörsken (2004), pp. 22, 26 placing 'values' in one line with notions like 'identity' or 'substance'.

${ }^{41}$ On how to distinguish these categories, see e.g. Habermas (1996), pp. 255 et seq.; Alexy (2009), pp. 86 et seq.; Dworkin (2013), pp. 38 et seq. Critically with regard to these distinctions, see Jakab (2016), p. 368.

${ }^{42}$ See Larik (2014).

${ }^{43}$ European Convention, Praesidium: Reactions to draft Articles 1 to 16 of the Constitutional Treaty, CONV 574/1/03, REV 1, pp. 17 et seq. See e.g. the suggestions for amendment by Ernâni Lopes and Manuel Lobo Antunes: 'Human dignity, liberty ... are principles and not mere values. Only principles may be legally binding and its violation invoked before a Court'; suggestion for amendment by Meglena Kuneva: 'Il serait préférable de garder la notion de 'principes', bien connue du droit communautaire et qui est employée par l'article 6 du TUE.' See also Plenary Session: Debate on Draft Articles 1 to 16 (27-28 February 2003). The minutes are accessible here: www. europarl.europa.eu/Europe2004/textes/verbatim_030227.htm. See e.g. 4-018 - Einem (Parl.-AT): 'Herr Präsident! . . w wir treten dafür ein, lieber von Grundsätzen - principles - statt von Werten valeurs - zu sprechen' or 4-083 - Kutskova (Gouv.-BG): 'Concerning Article 2, we consider it preferable to keep the notion of principles typical of the acquis'.

${ }^{44}$ Hilf and Schorkopf (2020), para. 21; von Bogdandy (2010), p. 21.

${ }^{45}$ Such uncertainties are provoked first and foremost by the Commission itself, European Commission, Reasoned Proposal in Accordance with Article 7(1) of the Treaty on European Union Regarding the Rule of Law in Poland, COM (2017) 835 final, para. 1: 'The Commission, beyond [!] its task to ensure the respect of EU law, is also responsible ... for guaranteeing the common values of the Union' (emphasis added). See further Möllers and Schneider (2018), p. 125.

${ }^{46}$ Dumbrovsky (2018).
} 
the legal framing of the Union's values seems almost inevitable. The rule of law warrants that normative requirements enforced by public institutions are laid down in the form of law. Otherwise, the mechanisms of Article 7 or Article 49 TEU would provide political morality with public authority without making it subject to any constitutional limitations. ${ }^{47}$ For this reason, Article 2 TEU values are necessarily part of EU law.

Yet, the views on their exact nature differ considerably. First, Article 2 values can be understood as 'rules', as they form legal parameters relevant for both the sanctioning mechanism under Article 7 and the admission procedure under Article 49 TEU. Second, one could argue that values are in fact 'principles' ${ }^{48}$ Indeed, the Treaty drafters used both notions in a rather undifferentiated way. ${ }^{49}$ Further, the 'values' enshrined in the first sentence of Article 2 TEU were termed 'principles' in Article 6(1) TEU-Nice/Amsterdam, which is generally understood as a predecessor of Article 2 TEU. Finally, one could perceive Article 2 TEU as a new form of legal category, which still has to be determined. Whatever the response to this question might be, one thing seems rather clear: Article 2 TEU does not only contain a set of rough ideals or solemn aspirations-it unfolds legal effects.

\subsection{Direct Effect: Are Article 2 TEU Values Directly Applicable?}

Nevertheless, the acknowledgment of legal effects does not necessarily entail Article 2 TEU's direct applicability (or even justiciability). ${ }^{50}$ Indeed, the values-for example, the rule of law-are extremely vague and open. ${ }^{51}$ Hence, it is not entirely clear whether Article 2 TEU fulfils the essential criteria for direct effect: A Treaty provision must be precise, clear, and unconditional. ${ }^{52}$ While these rigid criteria have often been criticized, ${ }^{53}$ recent jurisprudential developments indicate a more nuanced understanding of direct effect. Concerning the direct effect of Charter rights, the

\footnotetext{
${ }^{47}$ von Bogdandy (2020), p. 716.

${ }^{48}$ See e.g. von Bogdandy (2010), p. 22; Mangiameli (2012); Streinz (2018); Pérez de Nanclares (2019), p. 136.

${ }^{49}$ This becomes especially apparent in the preamble to the TEU. On one hand, the Treaty drafters draw 'inspiration from the ... universal values of the inviolable and inalienable rights of the human person, freedom, democracy, equality and the rule of law' on the other hand, they confirm 'their attachment to the principles of liberty, democracy and respect for human rights ... and of the rule of law'.

${ }^{50}$ Kochenov and Pech (2015), p. 520.

${ }^{51}$ On the need for a 'non-controversial' and thus deliberately open set of values, see European Convention, supra note 32, p. 11.

${ }^{52}$ See e.g. CJEU, Case C-176/12 Association de médiation sociale, ECLI:EU:C:2014:2, para. 36. Further Craig and de Búrca (2020), p. 223.

${ }^{53}$ See e.g. Wohlfahrt (2016) and Pescatore (1983).
} 
Court started to distinguish between two categories: ${ }^{54}$ first, 'mandatory effect', meaning that a provision is sufficient in itself to entail a right or obligation; ${ }^{55}$ and second, the 'unconditional nature', meaning that a right does not need 'to be given concrete expression by the provisions of EU or national law'. ${ }^{56}$

According to this recent understanding, the application of Article 2 TEU faces three options. First, Article 2 TEU could be perceived as mandatory and unconditional and thus apply as a self-standing provision. ${ }^{57}$ Second, Article 2 TEU could lack a mandatory effect but still be unconditional. In this case, Article 2 TEU could be considered by the CJEU or national courts through some sort of (non-binding?) value-oriented interpretation of $\mathrm{EU}$ and national law. A third option would be that Article 2 TEU is mandatory but not unconditional. It would need to be applied with a more specific provision giving concrete expression to the values enshrined in Article 2 TEU. ${ }^{58}$ Such a combined approach could be construed in two ways: On one hand, Article 2 TEU could be applied directly but informed by a more specific provision. On the other hand, one could apply a specific provision of EU law giving expression to a value enshrined in Article 2 TEU and thus operationalizing the latter.

\subsection{Jurisdiction: Does the Court Have Competence to Review the Member States' Value Compliance?}

Even if we assume that Article 2 TEU has direct effect and creates directly applicable (and thus in principle justiciable) obligations for the Member States, it is not said that the CJEU has jurisdiction to assess and enforce Article 2 TEU compliance in the Member States. Generally, the Court's competence encompasses the interpretation and assessment of the 'law' (Article 19(1)(1) TEU). This includes Union law in all its shapes, forms, and manifestations. ${ }^{59}$ In this light, it seems very likely that the

\footnotetext{
${ }^{54}$ See e.g. CJEU, Case C-684/16 Max-Planck-Gesellschaft, ECLI:EU:C:2018:874, para. 74; Case C-569/16 Bauer, ECLI:EU:C:2018:871, para. 85: 'Article 31(2) of the Charter, is thus, as regards its very existence, both mandatory and unconditional in nature' (emphasis added).

${ }^{55}$ CJEU, Case C-414/16 Egenberger, ECLI:EU:C:2018:257, paras. 76-77; Case C-193/17 Cresco Investigation, ECLI:EU:C:2019:43, para. 77.

${ }^{56} \mathrm{CJEU}$, Max-Planck-Gesellschaft, supra note 54, paras. 74, 78; Bauer, supra note 54, paras. 85,89 .

${ }^{57}$ For an approach relying directly on Art. 2 TEU yet specified i.a. via the Copenhagen Criteria, see Hillion (2016), pp. 66 et seq. This is further what the proposal of an 'systemic infringement action' boils down to, see Scheppele et al. (2020); Scheppele (2016); Skouris (2018), p. 50.

${ }^{58}$ For first sketches, see Cannizzaro (2018); Closa and Kochenov (2016b), pp. 182-184; Pech et al. (2016), p. 198.

${ }^{59}$ The CJEU has assessed recommendations (CJEU, Case C-322/88 Grimaldi, ECLI:EU: C:1989:646, paras. 7-8; Case C-16/16 P Belgium v. Commission, ECLI:EU:C:2018:79, para. 44), communications (CJEU, Case C-57/95 France v. Commission, ECLI:EU:C:1997:164, para. 23), guidelines (CJEU, C-233/02 France v. Commission, ECLI:EU:C:2004:173, para. 40), memoranda
} 
Court has a competence to interpret and assess Article 2 TEU as well. Yet it is highly debated whether the Article 7 TEU procedure and the Court's limited competence to review the latter (Article 269 TFEU) bar an assessment and enforcement of Article 2 TEU values via the Article 258 or 267 TFEU procedures ${ }^{60}$ - especially beyond the scope of application of (other) EU law. ${ }^{61}$

Nevertheless, there are good arguments in favour of the Court's jurisdiction. While the former Treaties have kept the EU's foundational principles out of the Court's reach, ${ }^{62}$ the Lisbon Treaty does not contain any comparable limitation with regard to Article 2 TEU. First, Article 269 TFEU is an exception to the CJEU's general competence under Article 19(1)(1) TEU, which must be interpreted narrowly. Second, the political Article 7 TEU and the judicial Article 258/267 TFEU procedures have very different objects and consequences. Article 7 TEU concentrates on a political situation and entails, as a last resort, the suspension of Member States' rights. In contrast, the Court adjudicates an individual case and its sanctioning powers are limited to Article 260 TFEU (penalty payments). ${ }^{63}$ For this reason, there seems to be no identity between the judicial and the political procedures that would afford exclusivity to the latter.

\section{Turning Article 2 TEU into a Judicially Applicable Provision}

In an emerging line of jurisprudence, the CJEU could be seen as resolving these uncertainties by developing Article 2 TEU into a judicially applicable provision justiciable before the Court. The pierre fondatrice of this emerging jurisprudence is the judgment in Associação Sindical dos Juizes Portugueses (ASJP). In this seminal case, the Court established the Member States' obligation to guarantee the judicial independence of virtually the whole national judiciary irrespective of any specific

(CJEU, Case C-258/14 Florescu, ECLI:EU:C:2017:448, para. 30) and even mere announcements (CJEU, Case C-62/14 Gauweiler, ECLI:EU:C:2015:400, para. 27).

${ }^{60}$ Arguing in favour of the Court's jurisdiction, see e.g. the Opinion of AG Tanchev in Case C-619/ 18, Commission v. Poland (Indépendance de la Cour suprême), para. 50; Rossi (2020), pp. 655-666; Giegerich (2019), p. 80; Skouris (2018), pp. 50 et seq.; Schmidt and Bogdanowicz (2018), pp. 1069-1073; Franzius (2018), p. 386; Hilf and Schorkopf (2020), para. 46; Waelbroeck and Oliver (2017), p. 335; Hillion (2016), pp. 71-73; Scheppele (2016), p. 114. Arguing for a restriction, see Levits (2018a), p. 521; Martenczuk (2018), pp. 46 et seq.; Nicolosi (2015), p. 643. ${ }^{61}$ Against the Court's jurisdiction outside the scope of EU law, see Lenaerts and Gutiérrez-Fons (2017), p. 774.

${ }^{62}$ According to Art. 46(d) TEU-Nice the CJEU was only competent for what was then Art. 6 (2) TEU-Nice but not for the 'principles' laid down in Art. 6(1) TEU-Nice. The CJEU nonetheless relied on them, see CJEU, Case C-402/05 P Kadi, ECLI:EU:C:2008:461, para. 303.

${ }^{63}$ This becomes most visible in L.M., where the Court rejected to generally suspend the EAW Framework with regard to Poland, see CJEU, Minister for Justice and Equality, supra note 36 , paras. 70 et seq. 
link to EU law (Sect. 3.1). Although this stance can also be reconstrued as a manifestation of the well-established effet utile rationale (Sect. 3.2), I propose a reading relying on Article 2 TEU. According to my understanding, the Court opted for a combined approach, operationalising Article 2 TEU through a specific provision of EU law (here Article 19(1)(2) TEU). This operationalisation, it is argued, leads to a 'mutual amplification' of both provisions: While the specific provision of EU law translates Article 2 TEU into a judicially applicable legal obligation, the operationalized Article 2 TEU charges and eventually extends the scope of application of the specific provision. Such a reading kills two birds with one stone: it leads to the judicial application of Article 2 TEU without limiting its unrestricted scope. As such, it allows reviewing and sanctioning any Member State action violating the Union's common values in judicial proceedings before the CJEU-irrespective of any link to other EU law. Finally, this approach is not confined to Article 19 TEU but could be extended to any provision giving expression to a value enshrined in Article 2 TUE (Sect. 3.3).

\subsection{The Groundbreaking Judgment in ASJP}

On its face, $A S J P$ seems like a rather innocent case. A Portuguese court asked the CJEU whether salary reductions for judges adopted in the context of an EU financial assistance program violated judicial independence. Generally, there are two Treaty provisions guaranteeing judicial independence: Article 47 CFR and Article 19(1) (2) TEU. The former only operates under the scope defined in Article 51(1) CFR. The salary reductions were part of spending cuts conditional for financial assistance under the EU financial crisis mechanisms. Since the Court already applied the Charter in comparable situations, ${ }^{64}$ Advocate General Øe proposed to grasp this thin material link and rely on the CFR. ${ }^{65}$ The CJEU could have followed this approach and $A S J P$ would have disappeared discreetly as another clarification of the meandering post-Åkerberg Fransson case law. Yet, this is not what happened. The Court referred to Article 19(1)(2) TEU, which stipulates that 'Member States shall provide remedies sufficient to ensure effective legal protection in the fields covered by Union law.' Such effective legal protection presupposes an independent judiciary. ${ }^{66}$

According to the Court, this obligation applies 'irrespective of whether the Member States are implementing Union law, within the meaning of Article 51 (1). ${ }^{67}$ This is already indicated by the different wording of both provisions. Article 19(1)(2) TEU limits its scope to 'the fields covered by Union law', whereas the

\footnotetext{
${ }^{64}$ See e.g. CJEU, Florescu, supra note 59.

${ }^{65}$ Opinion of AG Saugmandsgaard Øe, Case C-64/16, paras. 43-53.

${ }^{66} \mathrm{CJEU}$, Associação Sindical dos Juízes Portugueses, supra note 35, para. 36.

${ }^{67}$ Id., para. 29 (emphasis added).
} 
Charter applies to 'situations ... within the scope of European Union law'. 68 'Fields' are different from 'situations'. According to this semantic difference, 'fields covered by Union law' could be understood in a more extensive manner. ${ }^{69}$ But how broad should the scope of Article 19(1)(2) TEU be? The Court refers to the preliminary ruling mechanism under Article 267 TFEU: '[T]hat mechanism may be activated only by a body responsible for applying EU law which satisfies, inter alia, that criterion of independence'. 70 'Responsible for applying EU law' includes all authorities which are potentially in the situation of applying it. $^{71}$ This means practically every Member State court. ${ }^{72}$ For Article 19(1)(2) TEU to be triggered, it is not necessary that the respective Member State court actually adjudicates a matter of EU law in the specific case at hand; the mere potentiality of dealing with such matters suffices.

After the Court's stance in ASJP, Article 19(1)(2) TEU reaches even situations which do not present any other link to EU law. Accordingly, ASJP has been interpreted as establishing a "quasi-federal standard" ${ }^{73}$ for judicial independence. How does the Court justify this ample scope? A thorough analysis of ASJP reveals two (complementary) rationales, a functional and axiological one. ${ }^{74}$ A similar reading has been advanced by Advocate General Tanchev in Miasto Łowicz. According to him, the ample scope is justified because

Article 19 TEU is a concrete manifestation of the rule of law, one of the fundamental values on which the European Union is founded under Article 2 TEU, and Member States are bound under the second subparagraph of Article 19(1) TEU to 'provide remedies sufficient to ensure effective legal protection'. Structural breaches of judicial independence inevitably impact on the preliminary ruling mechanism under Article 267 TFEU and therefore on the capacity of Member State courts to act as EU Courts. ${ }^{75}$

In this sense, the CJEU's broad interpretation of Article 19(1)(2) TEU can be justified both by a recourse to the functioning of the EU's judicial system and the values enshrined in Article 2 TEU.

\footnotetext{
${ }^{68}$ CJEU, Åkerberg Fransson, supra note 27, para. 19. More recently, CJEU, Case C-117/14 Nisttahuz Poclava, ECLI:EU:C:2015:60, para. 29. But see Egenberger where the Court referred to Charter rights as applying 'in a field covered by EU law', supra note 55, para. 76. See also CJEU, Case C-68/17 IR, ECLI:EU:C:2018:696, para. 69.

${ }^{69}$ See for this interpretation Lenaerts (2019a); id. (2019b); Giegerich (2019), p. 76; von Danwitz (2018); Levits (2018b); Pech and Platon (2018), p. 1837; Miglio (2018), p. 426. On the problematic doctrinal implications of diverging scopes under Art. 19(1)(2) TEU and the Charter, see Spieker (2019b); Bonelli and Claes (2018), pp. 630-632.

${ }^{70} \mathrm{CJEU}$, Associação Sindical dos Juízes Portugueses, supra note 35, para. 43 (emphasis added).

${ }^{71}$ See also CJEU, Commission v. Poland (Indépendance de la Cour suprême), supra note 22, para. 51; AG Tanchev in Case C-558/18, Miasto Lowicz, paras. 87-88, 94, 125.

${ }^{72}$ Similarly, von Danwitz (2018); Pech and Platon (2018), p. 1838; Bonelli and Claes (2018), p. 623.

${ }^{73}$ Pech and Platon (2018), p. 1847; Adam and Van Elsuwege (2018), p. 341.

${ }^{74}$ See also von Bogdandy and Spieker (2019), pp. 413 et seq.

${ }^{75}$ Opinion of AG Tanchev in Case C-558/18, Miasto Łowicz, para. 92 (emphasis added).
} 


\subsection{First Rationale: Securing the Functioning of the EU's Judicial System}

At first sight, the CJEU seems to employ the well-established effet utile rationale. First, the Court refers to the functioning of the preliminary reference procedure in Article 267 TFEU. National courts have an indispensable position in the effective and uniform application of EU law. ${ }^{76}$ As they are obliged to apply EU law in the respective Member States even where it may conflict with national law, they are considered to be the first 'Union courts" ${ }^{, 77}$ and as such an arm of EU law. ${ }^{78}$ Such a system cannot work if Member State courts are not independent. Not without reason, one of the key pre-conditions for a court to be eligible for launching preliminary references is its independence. ${ }^{79}$ Second, the rationale behind Article 19(1)(2) TEU supports the Court's findings. Despite a limited extension of the demanding locus standi criteria for individual actions before the CJEU (see Article 263(4) TFEU), ${ }^{80}$ the drafters of the Lisbon Treaty retained the decentralized judicial system based on both the CJEU and Member State courts. ${ }^{81}$ The function of Article 19(1)(2) TEU is to ensure that this diffused judicial system works and that no protection gaps arise. ${ }^{82}$ This necessarily enables the CJEU to specify and harmonize Member States' provisions regarding judicial remedies and procedures. ${ }^{83}$ These two considerations seem to strongly indicate that the CJEU is relying on its well-known effet utile

\footnotetext{
${ }^{76}$ See e.g. CJEU, Case C-284/16 Achmea, ECLI:EU:C:2018:158, para. 36; Opinion 2/13 Accession of the EU to the ECHR II, para. 176; Opinion 1/09 Agreement creating a Unified Patent Litigation System, ECLI:EU:C:2011:123, paras. 84-85.

${ }^{77}$ See CJEU, Case C-106/77 Simmenthal, ECLI:EU:C:1978:49; Case C-294/83 Les Verts v. Parliament, ECLI:EU:C:1986:166; Unified Patent Litigation System, supra note 76, para. 80. See further Fennelly (2013).

${ }^{78}$ Lenaerts (2019b).

${ }^{79}$ For cases, in which the CJEU actually assessed the independence of the referring entity, see CJEU, Case C-203/14 Consorci Sanitari del Maresme, ECLI:EU:C:2015:664, para. 19; Case C-222/13 TDC, ECLI:EU:C:2014:2265, paras. 28-36; Joined Cases C-58/13 and C-59/13 Torresi, ECLI:EU:C:2014:2088, paras. 18-25; Case C-109/07 Pilato, ECLI:EU:C:2008:274, paras. 21-30; Case C-506/04 Wilson, ECLI:EU:C:2006:587, paras. 49 et seq.; Case C-53/03 Syfait, ECLI:EU: C:2005:333, paras. 29, 31; Case C-516/99 Schmid, ECLI:EU:C:2002:313, paras. 35 et seq.; Case C-407/98 Abrahamsson and Anderson, ECLI:EU:C:2000:367, paras. 29-37; Case C-103/97 Köllensperger and Atzwanger, ECLI:EU:C:1999:52, paras. 19-24; Case C-54/96 Dorsch Consult, ECLI:EU:C:1997:413, paras. 34-36. More generally, see Broberg and Fenger (2014), pp. 62 et seq. ${ }^{80}$ For a sharp critique of these demanding criteria, see the Opinion of AG Jacobs in Case C-50/00 P, Unión de Pequeños Agricultores, paras. 36-49; Konstadinidis (2017), pp. 111 et seq.

${ }^{81}$ See e.g. Tridimas (2013).

${ }^{82}$ See Lenaerts (2007), pp. 1629-1630.

${ }^{83}$ See e.g. CJEU, Case C-432/05 Unibet, ECLI:EU:C:2007:163, paras. 40-43; Case C-213/89 Factortame I, ECLI:EU:C:1990:257, paras. 19 et seq. See further da Cruz Vilaça (2013), pp. 300 et seq.; Lenaerts et al. (2014), pp. 107 et seq.
} 
argument. ${ }^{84}$ In this light, $A S J P$ could be read as an important step in the jurisprudential line of Simmenthal, Opinion 1/09 and Unibet.

\subsection{Second Rationale: Operationalizing the Values in Article 2 TEU}

Yet there is another, potentially groundbreaking explanation for the ample scope of Article 19(1)(2) TEU leaving the beaten tracks and venturing into uncharted territories of EU law. In the crucial passage of ASJP, the Court states that 'Art. 19 TEU ... gives concrete expression to the value of the rule of law stated in Article 2, ${ }^{85}$ According to my understanding, this recourse to values lays the groundworks for the judicial applicability of Article 2 TEU. The Court implicitly rejected a self-standing application of Article 2 TEU and opted for a combined approach (see supra Sect. 2.2). It operationalizes Article 2 TEU through a specific provision of EU law (here Article 19(1)(2) TEU). ${ }^{86}$ How does this operationalization work and what is its effect?

Like the Charter, Article 19(1)(2) TEU's scope of application is a derived one. It only applies within the 'fields covered by Union law' ${ }^{87}$ This means, however, that some kind of 'Union law' is needed to trigger its scope. Since Article 2 TEU presumably lacks direct effect and is thus no self-standing provision either, it would per se not allow for such a triggering. ${ }^{88}$ Taken in isolation, both provisions are therefore not applicable: Article 19 because of its derived scope and Article 2 TEU because of its lacking direct effect. What could be a way out of this impasse?

At first glance, Article 19(1)(2) TEU would have to be triggered by other Union law (e.g. a directive or fundamental freedoms). In consequence, Article 2 TEU operationalized by Article 19(1)(2) TEU would depend on the scope of other

\footnotetext{
${ }^{84}$ For such a 'functional' interpretation of ASJP, see also Schill and Krenn (2020), paras. 102 et seq.; Jaeger (2018), pp. 615 et seq. On a 'functional' scope of Art. 19(1)(2) TEU, see also Bonelli and Claes (2018), p. 631; Mickonyte (2019), pp. 830 et seq.

${ }^{85} \mathrm{CJEU}$, Associação Sindical dos Juízes Portugueses, supra note 35, para. 32 (emphasis added). Similarly, CJEU, Commission v. Poland (Indépendance de la Cour suprême), supra note 22, para. 47; Commission v. Poland (Indépendance des juridictions de droit commun), supra note 22, para. 98; Joined Cases C-585/18, C-624/18 and C-625/18 A.K. (Indépendance de la chambre disciplinaire de la Cour supreme), ECLI:EU:C:2019:982, para. 167. See also Opinion of AG Tanchev in Case C-192/18, Commission v. Poland (Indépendance des juridictions de droit commun), ECLI:EU:C:2019:529, para. 71; Opinion of AG Tanchev in Joined Cases C-585/18, C-624/18 and C-625/18, A.K. (Indépendance de la chambre disciplinaire de la Cour supreme), para. 77; Opinion of AG Tanchev in Case C-558/18, Miasto Łowicz, para. 92.

${ }^{86}$ von Bogdandy et al. (2018).

${ }^{87}$ On Art. 19(1)(2) TEU as a self-standing provision, see Pech and Platon (2018), pp. 1838, 1848.

${ }^{88}$ For a triggering relationship between Art. 2 TEU and Art. 51(1) CFR, see Jakab (2017), p. 255.
} 


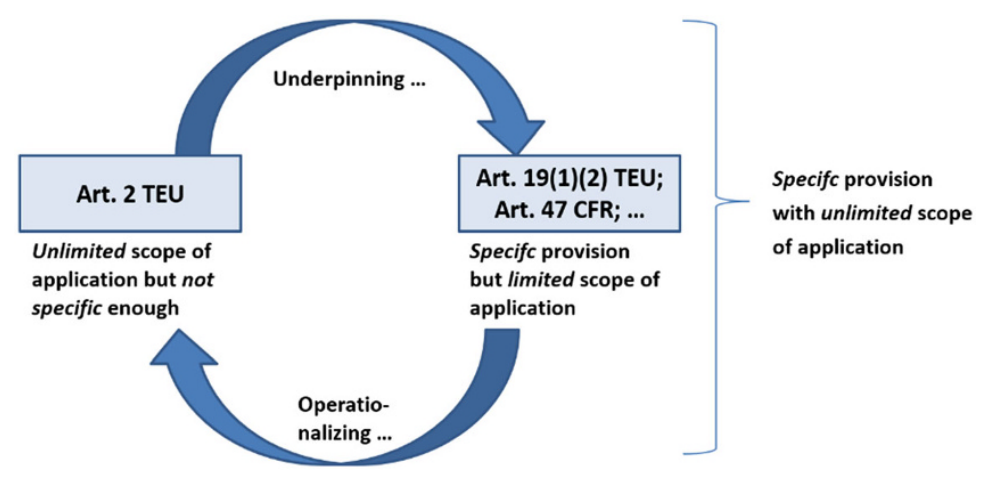

Fig. 1 Mutual amplification

Union law and could not operate beyond that ${ }^{89}$ Such a limitation, however, seems to severely neglect Article 2 TEU's foundational character and its unrestricted scope of application: The Member States are bound by it even in areas not covered by any (other) Union law. ${ }^{90}$ Limiting Article 2 TEU to the scope of other Union law would frustrate its overarching importance and deprive the recourse to Union values of any added-value.

And indeed, the CJEU did not seem to have limited the scope of Article 19(1) (2) TEU (operationalizing Article 2 TEU) to the scope of any other Union law applying. It established standards for practically any Member State court. How does the Court reach this conclusion? According to my understanding, the combined reading of Article 2 TEU with a specific provision leads to a cumulation of their legal effects-a mutual amplification: While the specific provision of EU law (here Article 19 TEU) translates Article 2 TEU into a specific legal obligation, the operationalized Article 2 TEU triggers and determines the scope of application of the specific provision. ${ }^{91}$ In this interplay, each contributes what the other lacksspecificity and scope (see Fig. 1).

As it is Article 2 TEU, which determines the scope, the operationalized obligations can apply beyond the scope of any other Union law to any Member State action. In this sense, the idea of mutual amplification kills two birds with one stone: It allows for the judicial applicability of Article 2 TEU through a specific provision without losing its unrestricted scope.

\footnotetext{
${ }^{89}$ This would also be the case if Article 2 TEU was operationalized by other provisions, like Charter rights or a specific directive.

${ }^{90}$ See supra note 32.

${ }^{91}$ See already Spieker (2019a), pp. 1204 et seq.; von Bogdandy and Spieker (2019), pp. 416 et seq. See also Rossi (2020), p. 650: 'c'est en réalité l'ancrage à l'article 2 et à ses valeurs suprêmes qui a permis de donner à l'article 19 , paragraphe $1, \ldots$ un épaisseur et une portée qu'avant l'arrêt Juízes Portugueses il aurait été difficile à imaginer. Il s'agit donc d'une "concretisation" au moins réciproque.'
} 
Eventually, this approach could be extended to any norm of EU law containing a specific obligation and 'giving expression' to values enshrined in Article 2 TEU. As already mentioned, Article 2 TEU contains the values of 'respect for human rights,' democracy, and the rule of law. The Charter can be understood as a specific realisation of these values. ${ }^{92}$ As such, a mutual amplification of Article 2 TEU and Charter rights seems possible.

The Court's judgment in L.M. could be a first, careful step in this direction. The case dealt with the surrender of a Polish national, who is wanted to face trial in Poland and was arrested in Ireland based on an European Arrest Warrant (EAW). The referring Irish High Court asked whether the surrender could be denied on the basis that the rule of law in Poland has been systematically damaged and the respective person would thus face trial in a jurisdiction where an independent judge is not guaranteed. The CJEU applied the two-pronged Aranyosi-test ${ }^{93}$ and extended it to violations of the essence of the right to a fair trial (Article 47 CFR).

While the CJEU left the final assessment of the situation in Poland to the referring court, this test eventually allows reviewing the conformity of a situation which falls at first glance beyond the scope of Union law with the essence of a Charter right. Although the issue of an EAW is clearly within the scope of Union law as defined by Article 51(1) CFR, this is not the case for what is scrutinized under the Aranyosi-test. In L.M., neither the Polish judicial reforms nor the specific domestic criminal proceedings presented any apparent link to EU law-except for Article 2 TEU. Nevertheless, the referring Court is under the obligation to examine this situation for its compliance with $E U$ standards (the essence of Article $47 \mathrm{CFR}$ ). One could of course argue that this review competence is a result of the specificities of mutual recognition regimes or that the assessment of the internal situation in Poland is only conducted indirectly in order to determine whether the EAW has to be executed or denied. Yet, similar to ASJP, the Court establishes a nexus between the essence of Article 47 CFR and Article 2 TEU:

Judicial independence forms part of the essence of the fundamental right to a fair trial ... which is of cardinal importance as a guarantee ... that the values common to the Member States set out in Article 2 TEU, in particular the value of the rule of law, will be safeguarded. ${ }^{94}$

In this spirit, the Court started to increasingly connect Article 2 TEU and Charter rights in its recent case law. In Tele 2 Sverige, for instance, the Court established a continuum between the freedom of expression under Article $11 \mathrm{CFR}$ and the value of

\footnotetext{
${ }^{92}$ Voßkuhle (2017), p. 114; Hilf and Schorkopf (2020), para. 36; Rossi (2020), p. 653.

${ }^{93}$ First, the applicant must demonstrate systemic deficiencies amounting to a real risk of inhumane and degrading treatment. Second, there must be 'substantial grounds to believe that the individual concerned will be exposed to that risk', see CJEU, Joined Cases C-404/15 and C-659/15 PPU, Aranyosi and Căldăraru, ECLI:EU:C:2016:198, paras. 89, 92.

${ }^{94} \mathrm{CJEU}$, Minister for Justice and Equality, supra note 36, para. 48. On this continuum between Art. 47 CFR and Art. 2 TEU, see also Wendel (2019), pp. 27-29.
} 
democracy under Article 2 TEU. ${ }^{95}$ In light of these links, one could argue that the concept of mutual amplification is not limited to the situation in ASJP, but instead open to all provisions of EU law giving concrete expression to Article 2 TEU values.

\section{Anticipating Objections and Advancing Rejoinders}

In sum, the Court's stance in ASJP could be interpreted as making the values in Article 2 TEU judicially applicable through a mutual amplification with a specific provisions of EU law. The decisions following ASJP reveal a twofold development. First, the Court is willing to scrutinize and sanction Member State actions under the operationalised Article 2 TEU. Although the CJEU refrained from finding any violation in ASJP, the judgment served as a stepping stone for the infringement proceedings against Poland. ${ }^{96}$ Second, the CJEU seems to develop the diffused and decentralized EU judicial network into a value monitoring and enforcement mechanism. Today, violations of operationalised Union values can reach the CJEU not only via infringement proceedings initiated by the Commission (constellation in Commission v. Poland) but also through preliminary reference procedures-either by 'brave' national courts directly against national measures (constellation in ASJP or A.K.) or by courts in other Member States assessing cooperation with backsliding Member States under mutual recognition regimes (constellation in L.M.).

Without a doubt, the proposed reading of ASJP and its progenies leads to a considerable development of the law. It seems to immensely extend the scope of Union law and the Court's jurisdiction. Indeed, no Member State area seems to escape the obligations stemming from Article 2 TEU. As such, Article 2 TEU could become the core of a European Constitution with federalizing potential, threatening the federal equilibrium established by the Treaties. Therefore, this proposal of activating Article 2 TEU will most certainly raise doubts and criticism. The following section aims at anticipating some of this critique by referring to one of the CJEU's most accomplished national counterparts-the Bundesverfassungsgericht (BVerfG).

\footnotetext{
${ }^{95}$ CJEU, Joined Cases C-203/15 and C-698/15 Tele2 Sverige, ECLI:EU:C:2016:970, para. 93: ' $[\mathrm{t}$ ] hat fundamental right, guaranteed in Article 11 of the Charter, constitutes one of the essential foundations of a pluralist, democratic society, and is one of the values on which, under Article 2 TEU, the Union is founded'. See also CJEU, Joined Cases C-511/18, C-512/18 and C-520/18 La Quadrature du Net, ECLI:EU:C:2020:791, para. 111; Case C-623/17 Privacy International, ECLI: EU:C:2020:790, para. 62; Case C-163/10 Patriciello, ECLI:EU:C:2011:543, para. 31. See further the connection between Art. 47 CFR and Art. 2 TEU in CJEU, Case C-72/15 Rosneft, ECLI:EU: C:2017:236, paras. 72-73.

${ }^{96} \mathrm{CJEU}$, Commission v. Poland (Indépendance de la Cour suprême), supra note 22.
} 


\subsection{Framing Possible Objections}

Generally, it seems uncontested that EU primary law is characterised by a special, evolutive dynamic ${ }^{97}$ and has to be interpreted accordingly. ${ }^{98}$ Due to the partial incompleteness of the EU legal order, the creative judicial development of the ${ }^{l a w}{ }^{99}$ has been an accepted feature of the CJEU's legal reasoning since the very beginning. ${ }^{100}$ This must apply especially in situations of new and unprecedented challenges that threaten the EU's very foundations.

There are, however, two key limits to such a judicial development of the law, which the BVerfG sketched out in Honeywell: ${ }^{101}$ Horizontally, the Court should respect the inter-institutional separation of powers. Accordingly, '[t]he Court of Justice is ... not precluded from refining the law by means of methodically bound case-law' respecting its judicial function. ${ }^{102}$ '[A]s long as the Court of Justice applies recognised methodological principles', the judicial development of the law by the CJEU has to be accepted. ${ }^{103}$ Vertically, a 'major limit on further development of the law by judges at Union level is the principle of conferral'. ${ }^{104}$ Under this premise, it is essential to anchor the proposed reading of ASJP and the idea of mutual amplification carefully in the Court's case law and established methods of legal reasoning. At the same time, its impact must be strictly limited in order to safeguard the Union's federal equilibrium epitomised by Articles 4(2) or 5(1) TEU.

\subsection{Methodologically Unsound?}

Despite evident difficulties in agreeing on a common European legal methodology, ${ }^{105}$ the CJEU's interpretation generally revolves around 'the spirit, the general scheme and the wording of the Treaty ${ }^{106}$ and concentrates especially on a mixture

\footnotetext{
${ }^{97}$ See e.g. the characterisation as 'Wandel-Verfassung' by Ipsen (1983), pp. 32, 51.

${ }^{98}$ Martens (2013), p. 475; Itzcovich (2009), pp. 549 et seq.; Bengoetxea (1993), pp. 251 et seq.

${ }^{99}$ The CJEU does not distinguish between 'interpretation' ('Auslegung') and 'development of the law' ('Rechtsfortbildung'), see Martens (2013), p. 503; Jestaedt (2014), p. 33.

${ }^{100}$ See BVerfG, 2 BvR 687/85, Kloppenburg, Judgment of 8 April 1987, paras. 58-60. See further Lecourt (1976), p. 236; Everling (2000); Lenaerts and Gutman (2006), p. 7.

${ }^{101}$ BVerfG, 2 BvR 2661/06, Honeywell, Order of 6 July 2010. See also Calliess (2005), p. 930; Lenaerts and Gutman (2006), pp. 45 et seq.; Roth (2011), p. 834.

${ }^{102}$ BVerfG, Honeywell, supra note 101, paras. 62, 64 (emphasis added).

${ }^{103}$ BVerfG, 2 BvE 13/13, OMT, Judgment of 21 June 2016, para. 161 (emphasis added). See also BVerfG, 2 BvR 859/15, PSPP, Judgment of 5 May 2020, para. 112.

${ }^{104}$ Id., para. 65.

${ }^{105}$ Dann (2005). In EU private law, see Fleischer (2011).

${ }^{106}$ CJEU, Van Gend en Loos, supra note 7. For a typology, see Lenaerts and Gutiérrez-Fons (2014) and Itzcovich (2009).
} 
of systematic and teleological considerations. ${ }^{107}$ On one hand, the Court can consider the telos of a respective provision itself. On the other hand, it can refer to a telos detached from said provision by referring to objectives or principles of the EU legal order. This second type could be described as systematic or meta-teleological interpretation. ${ }^{108}$ In this light, there is a twofold, interlocking methodological justification for the idea of mutual amplification between Article 2 TEU and a specific provision of EU law.

First, the Court can rely on a teleological, concretizing, or gap-filling interpretation of Article 2 TEU itself-a practice accepted, for example, by the BVerfG as a methodologically sound endeavour. ${ }^{109}$ Specifying the obligations enshrined in Article 2 TEU by relying on existing provisions of the acquis not only provides such specificity, but is also much more restrained than filling the gap solely based on case law and praetorian principles. In doing so, a parallel could be drawn to the Court's case law on Union objectives. Although these objectives do not have any direct effect, ${ }^{110}$ the Court found ways to make them judicially applicable. It stated that the Union's objectives 'are necessarily applied in combination with the respective chapters of the EC Treaty intended to give effect to those principles and objectives'. ${ }^{111}$

Second, the Court can employ a systematic or meta-teleological interpretation of the specific provision operationalizing Article 2 TEU (e.g. Article 19(1)(2) TEU, Charter rights or any other provision giving specific expression to Article 2 TEU). Although the existence of hierarchies in EU primary law is highly disputed, ${ }^{112}$ some provisions-like objectives-seem to have been treated as primus inter pares and served as guiding stars for its interpretation. ${ }^{113}$ After Lisbon, objectives seem to have been placed behind the Union's common values. Article 2 TEU symbolises a 'shift from a legal entity that ... exists to strive for certain goals to one which, above all, expounds what it stands for.' ${ }^{114}$ This shift should find its expression in the Court's

\footnotetext{
${ }^{107}$ See e.g. CJEU, Case C-283/81 CILFIT, ECLI:EU:C:1982:335, para. 20. On the difficulties to separate teleological and systemic interpretation, see Lenaerts and Gutiérrez-Fons (2014), p. 17.

${ }^{108}$ Maduro (2007), p. 5.

${ }^{109} \mathrm{BVerfG}$, Honeywell, supra note 101, para. 64 : 'There is particular reason for further development of the law by judges where programmes are fleshed out, gaps are closed ...'.

${ }^{110}$ See e.g. CJEU, Case C-339/89 Alsthom Atlantique, ECLI:EU:C:1991:28, paras. 8-9. See also Case C-260/89 ERT, ECLI:EU:C:1991:254, paras. 39-40.

${ }^{111}$ See e.g. CJEU, Case C-484/08 Caja de Ahorros, ECLI:EU:C:2010:309, para. 46 (emphasis added); Case C-293/03 My, ECLI:EU:C:2004:821, para. 29.

${ }^{112}$ Hinting towards the existence of hierarchies, see Kadi, supra note 62, para. 303; Opinion 1/91 EEA I, ECLI:EU:C:1991:490, para. 6. See further, Rosas and Armati (2018), pp. 53-55. Similarly, with regard to the former Art. I-2 of the European Constitution and Art. 6(1) TEU-Nice/Amsterdam, see Tridimas (2007), p. 16; Peters (2000), pp. 341 et seq.; Gaudin (1999), p. 6. Critically concerning any hierarchies in EU primary law, see Nettesheim (2006), pp. 740 et seq.

${ }^{113}$ See e.g. CJEU, Case C-85/76 Hoffmann-La Roche, ECLI:EU:C:1979:36, para. 125; Case C-53/ 81 Levin, ECLI:EU:C:1982:105, para. 15; Case C-6/72 Continental Can, ECLI:EU:C:1973:22, para. 24.

${ }^{114}$ Larik (2014), p. 951.
} 
legal methodology. Hence, it does not seem far-fetched to propose a new kind of meta-teleological interpretation — not in light of the Union's objectives, but in light of its common values: An axiological interpretation. ${ }^{115}$ Under this method, the specific provision would be interpreted in light of the Union's founding values as enshrined in Article 2 TEU. In case of specific provisions, which have no derived (like Article 19(1)(2) TEU or the Charter) but nonetheless a limited scope of application (e.g. cross-border requirements), this could lead to a careful teleological reduction of their restricted scope insofar as Article 2 TEU values are at stake. ${ }^{116}$

Eventually, the idea of a mutual amplification-two mutually complementing and reinforcing provisions-is not unprecedented in the Court's case law. In a rather recent line of cases, the Court had to decide on the interplay of rights stemming from directives and Charter rights in horizontal situations between private parties. These cases concerned the question of whether a national provision in a case between two individuals conformed with EU law-first with rights stemming from specific directives and second with EU fundamental rights. Directives do not apply horizontally. ${ }^{117}$ The fundamental rights at issue apply horizontally ${ }^{118}$ - yet they are accessory to the scope of Union law (Art. 51(1) CFR). Thus, the Charter applies only in case its scope is triggered by the directive. ${ }^{119}$ Taken in isolation, neither of them is applicable. The Court, however, relied on a creative solution based on the notorious Mangold judgment. ${ }^{120}$ Taken together, both the directive as well as the fundamental right contribute to what the other lacks: Scope and horizontal effect. The directive, although not directly applicable, has 'the effect of bringing within the scope of European Union law the national legislation at issue ..., which concerns a matter governed by that directive'. ${ }^{121}$ Once the scope is triggered, it is the Charter right that applies horizontally in the case at hand. To add another layer to this complex interplay, the Court applies the Charter right (or the general principle) in a manner that is exactly equivalent to the right enshrined in the directive. This becomes most apparent in Kücükdeveci, where the Court stated that Directive 2000/78 'gives

\footnotetext{
${ }^{115}$ On such a 'value-oriented' interpretation, see von Bogdandy and Spieker (2019), Potacs (2016) and Calliess (2009).

${ }^{116}$ On the high burdens for justifying the use of this method, see Jakab (2016), p. 19.

${ }^{117}$ See e.g. CJEU, Case C-122/17 Smith, ECLI:EU:C:2018:631, paras. 42-44.

${ }^{118}$ This has been confirmed by the CJEU in Bauer, supra note 54, paras. 79-90; Max-PlanckGesellschaft, supra note 54, paras. 75-79; Egenberger, supra note 55, para. 76; Cresco Investigation, supra note 55, para. 76; Association de médiation sociale, supra note 52, para. 47; with regard to general principles CJEU, Case C-441/14 Danks Industri, ECLI:EU:C:2016:278, para. 27; Case C-555/07 Kücükdeveci, ECLI:EU:C:2010:21, para. 51; Case C-144/04 Mangold, ECLI:EU: C:2005:709, para. 77.

${ }^{119}$ On Article 51(1) CFR requiring an obligation of EU law actually applying in the case at hand, see supra note 27.

${ }^{120}$ Mangold, supra note 118, para. 75; Kücükdeveci, supra note 118, para. 23. Critically BVerfG, Honeywell, supra note 101; Danish Supreme Court, 15/2014, Dansk Industri (DI) acting for Ajos $A / S$, Judgment of 6 December 2016.

${ }^{121}$ Kücükdeveci, supra note 118, para. 25. Similarly, Bauer, supra note 54, para. 53; Max-PlanckGesellschaft, supra note 54, para. 50.
} 
specific expression' to the general principle of non-discrimination. ${ }^{122}$ The Court $d e$ facto applied the Directive as the principle's (or right's) specific expression. ${ }^{123}$ As such, this reasoning is a perfect example for the cumulation of legal effects sketched out above: The general principle allows for the horizontal application, while the Directive triggers the scope of Union law and provides for specificity.

\subsection{Pretext for a Power Grab?}

Naturally, the bold reading of the Court's case law as proposed above has the potential of severely upsetting the Union's federal equilibrium epitomised by Articles 4(2) or 5(1) TEU. ${ }^{124}$ Therefore, it is essential to put safeguards in place ensuring that Article 2 TEU does not become the 'pretext for a power grab'. ${ }^{125}$ These essential safeguards, however, should not be applied in a way that frustrates the respect for Article 2 TEU values either. Both considerations have to be carefully balanced against each other. In my view, the outcome of this balancing exercise could be a threefold limitation ensuring Article 2 TEU's function and simultaneously providing a safety net for the 'federal bargain'.

Limiting the Obligations Enshrined in Article 2 TEU First, Article 2 TEU must be interpreted in a restrictive manner as being triggered only in exceptional situations. On the one hand, Article 2 TEU cannot impose high standards upon the Member States, since such an interpretation could not be squared with the legally guaranteed constitutional autonomy of the Member States. ${ }^{126}$ Concerning the 'respect for human rights', some have proposed operating with the concept of 'essence'. ${ }^{127}$ Insofar as the 'essence' of Charter rights is concerned, they are also protected as

\footnotetext{
${ }^{122}$ Kücükdeveci, supra note 118 , para. 21. See further CJEU, Cresco Investigation, supra note 55, para. 75; Case C-68/17 IR, ECLI:EU:C:2018:696, para. 67; Egenberger, supra note 55, paras. 47, 75; Dansk Industri, supra note 118, para. 35; Case C-447/09 Prigge, ECLI:EU:C:2011:573, para. 48; Case C-297-298/10 Hennigs and Mai, ECLI:EU:C:2011:560, para. 68. Similarly, MaxPlanck-Gesellschaft, supra note 54, para. 72; Bauer, supra note 54, para. 83.

${ }^{123}$ See even CJEU, Case C-132/11 Tyrolean Airways Tiroler Luftfahrt Gesellschaft, ECLI:EU: C:2012:329, para. 23: 'to be examined solely in the light of Directive 2000/78' (emphasis added).

${ }^{124}$ See e.g. the arguments of Poland in CJEU, Commission v. Poland (Indépendance de la Cour suprême), supra note 22, paras. 39-40.

${ }^{125}$ Kochenov (2017b), p. 443.

${ }^{126}$ For similar conceptions, see Voßkuhle (2017), p. 117 ('essential content'); Schroeder (2016b), p. 11 ('minimum standards'); Toggenburg and Grimheden (2016), p. 221 ('minimum constitutional cohesion'). See also European Convention, supra note 32, p. 11: 'This Article can thus only contain a hard core of values meeting two criteria at once: on one hand, they must be so fundamental that they lie at the very heart of a peaceful society practicing tolerance, justice and solidarity; on the other hand, they must have a clear non-controversial legal basis so that the Member States can discern the obligations resulting therefrom'.

${ }^{127}$ von Bogdandy et al. (2012), pp. 509 et seq.; on the notion of 'essence', see further Brkan (2018); Lenaerts (2019c). See further the special issue in 20 German Law Journal 763 (2019).
} 
values under Article 2 TEU, while Article 51(1) CFR continues to delimit the application of the full fundamental right acquis. On the other hand, Article 2 TEU can hardly force detailed obligations upon the Member States, because this would ignore the actually existing constitutional pluralism in the Union. Due to the practically countless possibilities of how to bring the abstract values to life, Article 2 TEU cannot - from a mere practical perspective-be understood as containing very detailed obligations. ${ }^{128}$ Accordingly, Article 2 TEU's high degree of abstraction necessarily correlates with a lower degree of review by the Court. Where does that leave us? One feasible solution could be to understand Article 2 TEU as establishing only a regime of 'red lines'. ${ }^{129}$ On a conceptual level, Article 2 TEU would determine negatively what is not allowed, without positively determining how things should be instead. In a nutshell, Article 2 TEU would apply only in exceptional situations and only in the form of 'red lines'.

Limiting the EU's Competence Second, I argue that the Union's 'Verbandskompetenz' (its competence as a legal order) to enforce Member State's Article 2 TEU compliance beyond the scope of (any other) Union law is limited to the thresholds of Article 7 TEU. Indeed, the only provision explicitly empowering the EU legal order to enforce EU values or sanction violations thereof beyond the scope of (any other) Union law is Article 7 TEU. Hence, this provision contains a strong indication that the EU's Verbandskompetenz is limited at least to the substantive thresholds triggering Article 7 TEU (a 'serious and persistent breach'). ${ }^{130}$ This could provide the starting point for a workable restriction operating in form of a sliding scale (see Fig. 2): The more or the clearer a situation falls within the scope of

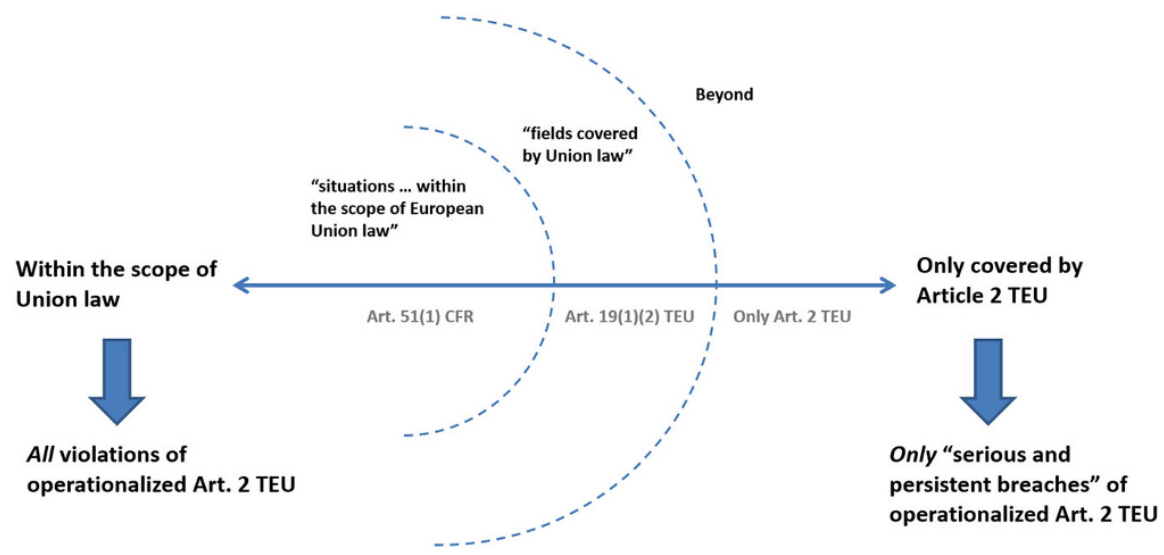

Fig. 2 Sliding Article 7 TEU scale

\footnotetext{
${ }^{128}$ von Bogdandy (2010), p. 40.

${ }^{129}$ von Bogdandy et al. (2018).

${ }^{130}$ See similar Council of the European Union, Opinion of the Legal Service, supra note 32, para. 17.
} 
other EU law, the more the EU and the less the respective Member State is affected. This means that in case of a clear link to EU law, every violation of Article 2 TEU values can be sanctioned by EU institutions (e.g. under the Charter). If the link is weaker or nonexistent, it approaches the confines of Article 7 TEU. To assess and sanction every violation in such situations would exceed the EU's Verbandskompetenz. Therefore, the more the situation departs from the scope of Union law and comes solely under Article 2 TEU, the more a violation must reach the thresholds of Article 7, and the more it must constitute a 'serious and persistent' breach to be claimed before the CJEU.

Limiting the Exercise of the CJEU's Jurisdiction Finally, there are several ways in which the CJEU might limit the exercise of its jurisdiction over Article 2 TEU: First, as proposed by the Reverse Solange doctrine, the Court could introduce a presumption of value compliance accompanied by a high threshold for its rebuttal. Such a threshold could be fixed on the level of systemic deficiencies-a notion which is well-established throughout the European legal space. ${ }^{131}$ Therefore, simple and isolated infringements upon the values enshrined in Article 2 TEU would not suffice to rebut the proposed presumption. The justification for such a presumption could be derived from the principle of mutual trust. Although mutual trust has been invoked only horizontally between the Member States, ${ }^{132}$ this does not mean that it excluded in the vertical relationship of EU and Member States. Indeed, mutual trust is based on or at least intrinsically linked to the principle of loyal and sincere cooperation in Article 4(3) TEU. ${ }^{133}$ The principle of mutual loyalty, however, expressly extends to Union institutions and hence the CJEU as well. ${ }^{134}$ Similar developments could be predicted for the principle of mutual trust.

A second option could consist of a more deferential approach, leaving the final determination of value compliance in the hands of national courts - at least in case of preliminary references. Indeed, the Court can vary and adjust the degree of specificity it applies. ${ }^{135}$ While it sometimes leaves the final determination to the referring court, ${ }^{136}$ it can also fully assess the situation in the respective Member

\footnotetext{
${ }^{131}$ See von Bogdandy and Spieker (2019), p. 424; further von Bogdandy and Ioannidis (2014).

${ }^{132} \mathrm{CJEU}$, Associação Sindical dos Juízes Portugueses, supra note 35, para. 30; Minister for Justice and Equality, supra note 36, para. 35.

${ }^{133}$ See e.g. CJEU, Case C-5/94 Hedley Lomas, ECLI:EU:C:1996:205, para. 19. See further AG Ruiz-Jarabo Colomer in Case C-297/07, Bourquain, para. 45: 'experience shows that mutual trust applies ... fulfilling a role similar to that of loyal cooperation'. See also Meyer (2017), pp. 179 et seq.; Prechal (2017), pp. 90-92; Gerard (2016), p. 76. But see Lenaerts (2017b), p. 807 who derives it from the principle of equality between the Member States.

${ }^{134}$ See the wording of Article 4(3) TEU. See further CJEU, Case C-339/00 Ireland v. Commission, ECLI:EU:C:2003:545, para. 72; Case C-197/13 Spain v. Commission, ECLI:EU:C:2014:2157, para. 87.

${ }^{135}$ On deference in the CJEU's jurisprudence, see e.g. Zglinski (2018).

${ }^{136}$ See e.g. Minister for Justice and Equality, supra note 36.
} 
State. ${ }^{137}$ These variations are no random exercise but a conscious judicial choice. ${ }^{138}$ A differential approach can not only lead to a burden sharing between the interacting courts but is also more respectful towards national autonomy. ${ }^{139}$ The Court's stance in L.M. and in A.K. especially could be understood as an expression of this deferential attitude. Yet deference does not come without risks. In A.K., for instance, the Court left the final decision of whether the new Polish disciplinary chamber violates judicial independence to the referring court. ${ }^{140}$ Thus, both the Polish government as well as the affected judiciary tried to capitalize on the judgment and claimed it as a victory. ${ }^{141}$ The referring court decided that the disciplinary chamber does not comply with the standards of independence set out by the CJEU. ${ }^{142}$ Instead of changing the problematic appointment procedures, however, the Polish government countered with a new bill aimed at tightening its control over the judiciary and preventing judges from questioning the independence of peers. ${ }^{143}$ Further, it increased its disciplinary proceedings against critical judges. ${ }^{144}$ As these continuing attacks demonstrate, deference is a two-edged sword: While it shows greater respect for national autonomy and diversity, it risks leaving affected national courts with a burden too heavy to shoulder. In this sense, the CJEU will have to carefully assess the situation in the respective Member State before determining the degree of deference applied.

\footnotetext{
${ }^{137}$ See e.g. CJEU, Associação Sindical dos Juízes Portugueses, supra note 35. Concerning systemic deficiencies, see e.g. CJEU, Joined Cases C-411/10 and C-493/10 N.S. and Others, ECLI:EU: C:2011:865; Case C-220/18 PPU Generalstaatsanwaltschaft (Conditions de détention en Hongrie), ECLI:EU:C:2018:589.

${ }^{138}$ Tridimas (2011), p. 749.

${ }^{139}$ See also Schiffauer (2019), p. 568.

${ }^{140} \mathrm{CJEU}$, A.K. (Indépendance de la chambre disciplinaire de la Cour supreme), supra note 85.

${ }^{141}$ For the statements of the Minister of Justice, see e.g. Ziobro o wyroku TSUE: Wielka porażka nadzwyczajnej kasty, Do Rzeczy (19 November 2019), dorzeczy.pl/kraj/120931/ziobro-o-wyrokutsue-wielka-porazka-nadzwyczajnej-kasty.html.

${ }^{142}$ Polish Supreme Court, Judgment of 5 December 2019, Case III PO 7/18; Judgments of 15 December 2020, Cases III PO 8/18 and III PO 9/18. See also the Resolution of three joint chambers of the Polish Supreme Court of 23 January 2020, Case BSA I-4110-1/20. In two rulings, however, the captured Polish Constitutional Tribunal declared the resolution to be unconstitutional, see Polish Constitutional Tribunal, Decision of 21 April 2020, Kpt 1/20; Decision of 20 April 2020, U 2/20. See further European Commission, 2020 Rule of Law Report Country Chapter on the rule of law situation in Poland (30 September 2020), SWD(2020) 320 final, pp. 4 et seq.

${ }^{143}$ For critical accounts, see e.g. Venice Commission, Poland-Urgent Joint Opinion on the amendments to the Law on organisation on the Common Courts, the Law on the Supreme Court and other Laws, CDL-PI(2020)002-e (16 January 2020); ODHIR, Urgent Interim Opinion on the Bill Amending the Act on the Organization of Common Courts, the Act on the Supreme Court and Certain Other Acts of Poland, JUD-POL/365/2019 [AlC] (14 January 2020); Polish Commissioner for Human Rights Adam Bodnar, Comments, VII.510.176.2019/MAW/PKR/PF/MW/CW (7 January 2020).

${ }^{144}$ See e.g. PACE, Report-The functioning of democratic institutions in Poland, Doc. 15025 (6 January 2020), paras. 95 et seq. See further Gajda-Roszczynialska, Markiewicz (2020).
} 


\section{Conclusion}

In entering the European Union and opening their respective legal orders for direct effect and primacy, the Member States simultaneously accepted an openness towards internal developments and decisions taken by other Member States. The EU does not only extend the 'transnational reach' of each Member State, but also creates a situation of mutual vulnerability. ${ }^{145}$ Internal developments in one Member State can lead to spill-over effects in all other Member States. The complex network of cooperation created by the European Union is not only enabling, it is transmitting and intensifying these effects. Especially through the introduction of majority decisions in the Council, each Member State partially and indirectly governs all others. As Commissioner Jourova put it: 'the EU is like a chain of Christmas lights. When one light goes off, others don't light up and the chain is dark.' ${ }^{146}$ Therefore, it is of utmost importance to secure Member States' adherence to the Union's common values as an underlying basis and essential safety net on which cooperation can take place.

The last 2 years have shown that the Court seems more than willing to protect this common value basis against the illiberal turn in some Member States. The judgment in ASJP especially represents a veritable stepping stone towards a strong union of values - a judgment on par with van Gend en Loos, Costa/ENEL, or Les Verts. ${ }^{147}$ With ASJP, the Court turned Article 2 TEU into a judicially applicable provision and paved the way for its activation in the EU value crisis. According to the interpretation advanced in this chapter, the Court renders Article 2 TEU applicable by operationalizing it through specific provisions of EU law without, however, losing its unrestricted scope. Due to this mutual amplification, any Member State act can be scrutinized under the operationalised Article 2 TEU-albeit under very restrictive conditions and only in very exceptional circumstances. As such, Article 2 TEU has become the Archimedean point for judicial proceedings against backsliding Member States.

Acknowledgments I am grateful to the Dienstagsrunde, especially Armin von Bogdandy, Iris Canor, Pedro Cruz Villalón, Michael Ioannidis, Christoph Krenn and Eva Neumann as well as Lukas Huthmann, Nicole Lazzerini, Andreas Orator, Anca Mihaela Rusu, Marie-Sophie Schäfer, and Pál Sonnevend for their comments and inspirations on this chapter and earlier drafts.

\section{References}

Adam S, Van Elsuwege P (2018) L'exigence d'independance du juge, paradigme de l'Union européenne comme union de droit. J de droit européen:334-343

Alexy R (2009) A theory of constitutional rights. Oxford University Press, Oxford

\footnotetext{
${ }^{145}$ For an analysis of these effects, see Somek (2010).

${ }^{146}$ Jourova (2017).

${ }^{147}$ For this perception, see Lenaerts (2019d).
} 
Baratta R (2018) La 'communauté de valeurs' dans l'ordre juridique de l'Union européenne. Revue des affaires européens:81-91

Bengoetxea J (1993) The legal reasoning of the European Court of Justice. Oxford University Press, Oxford

Bernatt M, Ziółkowski M (2018) Statutory anti-constitutionalism. Wash Int Law J 28:487-526

Blauberger M, Kelemen RD (2017) Can courts rescue national democracy? J Eur Public Policy 24:321-336

Bonelli M, Claes M (2018) Judicial serendipity: how Portuguese judges came to the rescue of the Polish judiciary. Eur Const Law Rev 14:622-643

Borowsky M (2014) Art. 51 - Anwendungsbereich. In: Meyer J (ed) Charta der Grundrechte der Europäischen Union, 4th edn. Nomos, Baden Baden

Brkan M (2018) The concept of essence of fundamental rights in the EU legal order: peeling the onion to its core. Eur Const Law Rev 14:332-368

Broberg M, Fenger N (2014) Preliminary references to the European Court of Justice, 2nd edn. Oxford University Press, Oxford

Calliess C (2005) Grundlagen, Grenzen und Perspektiven europäischen Richterrechts. NJW 58:929-933

Calliess C (2009) The transnationalization of values by European Law. German Law J 10:1367-1382

Calliess C (2016) Art. 2 EUV. In: Calliess C, Ruffert M (eds) EUV/AEUV, 5th edn. C.H.Beck, Munich

Cannizzaro E (2018) I ruolo della Corte di giustizia nella tutela dei valori dell'Unione europea. In: Liber Amicorum Antonio Tizzano. Giappichelli, Milan, pp 159-169

Carrera S, Guild E, Hernanz N (2013) The triangular relationship between fundamental rights, democracy and the rule of law in the EU. European Parliament, LIBE Committee. www. europarl.europa.eu/RegData/etudes/etudes/join/2013/493031/IPOL-LIBE_ET(2013)493031_ EN.pdf. Accessed 20 Oct 2020

Closa C (2016) Reinforcing EU monitoring of the rule of law, normative arguments, institutional proposals and the procedural limitations. In: Closa C, Kochenov D (eds) Reinforcing rule of law oversight in the European Union. Cambridge University Press, Cambridge, pp 15-35

Closa C, Kochenov D (eds) (2016a) Reinforcing rule of law oversight in the European Union. Cambridge University Press, Cambridge

Closa C, Kochenov D (2016b) Reinforcing the rule of law oversight in the European Union: key options. In: Schroeder W (ed) Strengthening the rule of law in Europe. Hart, Oxford, pp 173-196

Craig P, de Búrca G (2020) EU law, 7th edn. Oxford University Press, Oxford

da Cruz Vilaça JL (2013) Le principe de l'effet utile du droit de l'Union dans la jurisprudence de la Cour. In: Rosas A, Levits E, Bot Y (eds) The Court of Justice and the construction of Europe. T.M.C. Asser Press, The Hague, pp 279-308

Dann P (2005) Thoughts on a methodology of European constitutional law. German Law J 6:1453-1473

Dawson M, Muir E (2013) Hungary and the indirect protection of EU fundamental rights and the rule of law. German Law J 14:1959-1979

de Búrca G (2011) The evolution of EU human rights. In: Craig P, de Búrca G (eds) The evolution of EU law, 2nd edn. Oxford University Press, Oxford, pp 464-498

Dumbrovsky T (2018) Beyond voting rights suspension. Tailored sanctions as democracy catalyst under Article 7 TEU. In: Hatje A, Tichý L (eds) Liability of member states for the violation of fundamental values. Europarecht Beiheft 1/2018. Nomos, Baden Baden, pp 201-228

Dworkin R (2013) Taking rights seriously. Bloomsbury, London. (reprint of 1978)

Easton D (1965) A systems analysis of political life. University of Chicago Press, Chicago

EU Fundamental Rights Agency (2014) Fundamental rights: challenges and achievements in 2013 - annual report 2013 
Everling U (2000) On judge-made law of the European community's courts. In: O'Keeffe D (ed) Judicial review in European Union law. Kluwer Law International, The Hague, pp 29-44

Everling U (2015) Justizielle Krisenbewältigung: Der EuGH als Garant des europäischen Rechts. In: Hatje A (ed) Verfassungszustand und Verfassungsentwicklung der Europäischen Union. Europarecht Beiheft 2/2015. Nomos, Baden Baden, pp 86-103

Falkner G (2018) A causal loop? The Commission's new enforcement approach in the context of non-compliance with EU law even after CJEU judgments. J Eur Integr 40:769-784

Fennelly N (2013) The national judge as judge of the European Union. In: Rosas A, Levits E, Bot Y (eds) The Court of Justice and the construction of Europe. T.M.C. Asser Press, The Hague, pp 61-70

Fleischer H (2011) Europäische Methodenlehre: Stand und Perspektiven. Rabel J Comp Int Private Law 75:700-729

Franzius C (2018) Der Kampf um Demokratie in Polen und Ungarn - Wie kann und soll die Europäische Union reagieren? Die Öffentliche Verwaltung 71:381-388

Gajda-Roszczynialska K, Markiewicz K (2020) Disciplinary proceedings as an instrument for breaking the rule of law in Poland. Hague J Rule Law

Gaudin H (1999) Amsterdam: l'échec de la hiérarchie des normes? Revue trimestrielle de droit européen 35:1-20

Gerard D (2016) Mutual trust as constitutionalism? In: Brouwer E, Gerard D (eds) Mapping mutual trust. Understanding and framing the role of mutual trust in EU LAW. EUI Working Papers MWP 2016/1, Florence. Cadmus, Port Angeles, pp 69-79

Giegerich T (2019) Die Unabhängigkeit der Gerichte als Strukturvorgabe der Unionsverfassung. ZEuS 22:61-112

Habermas J (1996) Between facts and norms. Polity Press, Cambridge

Habermas J (2005) On the internal relation between the rule of law and democracy. In: Cronin C, De Greiff PP (eds) The inclusion of the other. Studies on political theory. Polity Press, Cambridge, pp 253-264

Halmai G (2017) The case of the retirement age of Hungarian judges. In: Nicola F, Davies B (eds) EU law stories. Contextual and critical histories of European jurisprudence. Cambridge University Press, Cambridge, pp 471-488

Hilf M, Schorkopf F (2020) Art. 2 EUV. In: Grabitz E, Hilf M, Nettesheim M (eds) Das Recht der Europäischen Union. C.H. Beck, Munich

Hillion C (2016) Overseeing the rule of law in the EU: legal mandate and means. In: Closa C, Kochenov D (eds) Reinforcing rule of law oversight in the European Union. Cambridge University Press, Cambridge, pp 59-81

Iliopoulou-Penot A (2019) La justification de l'intervention de l'Union pour la garantie de l'Etat de droit au sein des pays membres. Revue des affaires européennes:7-16

Ipsen HP (1983) Die Verfassungsrolle des Europäischen Gerichtshofs für die Integration. In: Schwarze J (ed) Der Europäische Gerichtshof als Verfassungsgericht und Rechtsschutzinstanz. Nomos, Baden Baden, pp 29-67

Itzcovich G (2009) The interpretation of community law by the European Court of Justice. German Law J 10:537-560

Jaeger T (2018) Gerichtsorganisation und EU-Recht: Eine Standortbestimmung. Europarecht 53:611-653

Jakab A (2016) European constitutional language. Cambridge University Press, Cambridge

Jakab A (2017) Application of the EU CFR by national courts in purely domestic cases. In: Jakab A, Kochenov D (eds) The enforcement of EU law and values. Oxford University Press, Oxford, pp 252-262

Jakab A (2020) What can constitutional law do against the erosion of democracy and the rule of law? On the interconnectedness of the protection of democracy and the rule of law. Const Stud 6:5-34

Jakab A, Kochenov D (eds) (2017) The enforcement of EU law and values. Oxford University Press, Oxford 
Jestaedt M (2014) Luxemburger Richterrecht. In: Hillgruber C (ed) Gouvernement des Juges Fluch oder Segen. Schöningh, Paderborn, pp 21-44

Jourova V (2017) Speech at the high level seminar: Finland 100 years - Finnish and European perspectives to the Rule of Law (31 October 2017)

Klamert M, Kochenov D (2019) Article 2 TEU. In: Kellerbauer M, Klamert M, Tomkin J (eds) The Treaties and the Charter of fundamental rights - a commentary. Oxford University Press, Oxford, pp 22-30

Kochenov D (2017a) The acquis and its principles, the enforcement of the 'Law' versus the enforcement of 'Values' in the EU. In: Jakab A, Kochenov D (eds) The enforcement of EU law and values. Oxford University Press, Oxford, pp 9-27

Kochenov D (2017b) The EU and the rule of law - Naïveté or a grand design? In: Adams M, Anne Meuwese A, Hirsch Ballin E (eds) Constitutionalism and the rule of law. Cambridge University Press, Cambridge, pp 419-445

Kochenov D, Bárd P (2019) The last soldier standing? Courts versus politicians and the rule of law crisis in the new member states of the EU. Eur Yearb Const Law 1:243-287

Kochenov D, Pech L (2015) Monitoring and enforcement of the rule of law in the EU: rhetoric and reality. Eur Const Rev 11:512-540

Konstadinidis T (2017) The rule of law in the European Union: the internal dimension. Hart, Oxford

Krenn C, Farahat A (2018) Der Europäische Gerichtshof in der Eurokrise: eine konflikttheoretische Perspektive. Der Staat 57:357-385

Ladenburger C (2012) European Union institutional report. In: Laffranque J (ed) Protection of fundamental rights post-Lisbon. Reports of the XXV FIDE congress. Tartu University Press, Tallinn, p 141

Landau D (2013) Abusive constitutionalism. UC Davis Law Rev 47:189-260

Larik J (2014) From speciality to a constitutional sense of purpose: on the changing role of the objectives of the European Union. Int Comp Law Q 63:935-962

Lazzerini N (2018) La Carta dei Diritti Fondamentali dell'Unione Europea. I Limiti di Applicazione. Franco Angeli, Milan

Lecourt R (1976) L'Europe des juges. Bruylant, Brussels. (reprint 2008)

Lenaerts K (1992) Some thoughts about the interaction between judges and politicians in the European community. Yearb Eur Law 12:1-34

Lenaerts K (2007) The rule of law and coherence of the judicial system of the European Union. Common Market Law Rev 44:1625-1659

Lenaerts K (2017a) Die Werte der Europäischen Union in der Rechtsprechung des Gerichtshofs der Europäischen Union. Europäische Grundrechte-Zeitschrift 44:639-642

Lenaerts K (2017b) La vie après l'avis: exploring the principle of mutual (yet not blind) trust. Common Market Law Rev 54:805-840

Lenaerts K (2019a) Upholding the rule of law through judicial dialogue. Yearb Eur Law 38:3-17

Lenaerts K (2019b) On judicial independence and the quest for national, supranational and transnational justice. In: Selvik $\mathrm{G}$ et al (eds) The art of judicial reasoning. Festschrift in Honour of Carl Baudenbacher. Springer, Heidelberg, pp 155-174

Lenaerts K (2019c) Limits on limitations: the essence of fundamental rights in the EU. German Law J 20:779-793

Lenaerts K (2019d) Upholding the rule of law within the EU. Speech held at the RECONNECT conference 'Democracy and the Rule of Law in the EU', 5 July 2019. reconnect-europe.eu/ events/conference-2019/

Lenaerts K, Gutiérrez-Fons JA (2014) To say what the law of the EU is: methods of interpretation and the European Court of Justice. Columb J Eur Law 20:3-61

Lenaerts K, Gutiérrez-Fons JA (2017) Epilogue on EU citizenship: hopes and fears? In: Kochenov D (ed) EU citizenship and federalism. The role of rights. Cambridge University Press, Cambridge, pp 751-781 
Lenaerts K, Gutman K (2006) 'Federal Common Law' in the European Union. Am J Comp Law $54: 1-122$

Lenaerts K, Maselis I, Gutman K (2014) EU procedural law. Oxford University Press, Oxford

Levits E (2018a) L’Union européenne en tant que communauté de valeurs partagées: les conséquences juridiques des articles 2 et 7 du traité sur l'Union européenne pour les États membre. In: Liber Amicorum Antonio Tizzano. Giappichelli, Milan, pp 509-522

Levits E (2018b) Die Europäische Union als Wertegemeinschaft. In: Jaeger (ed) Europa 4.0. Jan Sramek Verlag, Wien, pp 239-270

Luhmann N (1989) Legitimation durch Verfahren, 2nd edn. Suhrkamp, Frankfurt am Main

Maduro MP (2007) Interpreting European Law: judicial adjudication in a context of constitutional pluralism. Eur J Legal Stud 1:1-21

Maduro MP, Menezes Queiroz B (2020) A hard law approach to states systemic violations of Article 2 of the Treaty of the European Union. Reasons and means. In: Fisher E, King J, Young A (eds) The foundations and future of public law. Oxford University Press, Oxford, pp 363-380

Mancini GF (1989) The making of a constitution for Europe. Common Market Law Rev 26:595-614

Mangiameli S (2012) The Union's homogeneity and its common values in the Treaty on European Union. In: Blanke H-J, Mangiameli S (eds) The European Union after Lisbon. Springer, Heidelberg, pp 21-46

Martenczuk B (2018) Art. 7 EUV und der Rechtsstaatsrahmen als Instrument der Wahrung der Grundwerte der Union. In: Kadelbach S (ed) Verfassungskrisen in der Europäischen Union. Nomos, Baden Baden, pp 41-60

Martens SAE (2013) Methodenlehre des Unionsrechts. Mohr Siebeck, Tübingen

Mayoral JA (2016) In the CJEU judges trust: a new approach in the judicial construction of Europe. J Common Market Stud 55:551-568

Mendelski M (2016) Das europäische Evaluierungsdezifit der Rechtsstaatlichkeit. Leviathan 44:366-398

Meyer F (2017) Der Grundsatz gegenseitigen Vertrauens - Konzeptualisierung und Zukunftsperspektiven eines neuen Verfassungsprinzips. Europarecht 52:163-185

Mickonyte A (2019) Effects of the rule-of-law crisis in the EU: towards centralization of the EU system of judicial protection. ZaöRV 79:815-840

Miglio A (2018) Indipendenza del giudice, crisi dello stato di diritto e tutela giurisdizionale effettiva. Diritti Umani e Diritto Internazionale 12:421-432

Möllers C (2013) The three branches: a comparative model of separation of powers. Oxford University Press, Oxford

Möllers C, Schneider L (2018) Demokratiesicherung in der Europäischen Union. Studie zu einer europäischen Aufgabe. Mohr Siebeck, Tübingen

Nettesheim M (2006) Normenhierarchien im EU-Recht. Europarecht 41:737-772

Nicolosi SF (2015) The contribution of the Court of Justice to the codification of the founding values of the European Union. Revista De Derecho Comunitario Europeo 19(51):613-643

Niedobitek M (2018) Right and duty to pursue the 'wrongdoer' and a possible abuse of Art. 7 TEU. In: Hatje A, Tichý L (eds) Liability of member states for the violation of fundamental values. Europarecht Beiheft 1/2018. Nomos, Baden Baden, pp 233-242

Orbán V (2017) Speech at the 28th Bálványos Summer Open University (22 July 2017)

Pech L, Platon S (2018) Judicial independence under threat: the Court of Justice to the rescue in the ASJP case. Common Market Law Rev 55:1827-1854

Pech L et al (2016) An EU mechanism on democracy, the rule of law and fundamental rights, European Parliament, EPRS. www.europarl.europa.eu/EPRS/EPRS_STUD_579328_annexI_ EU_Mechanism_MILIEU.pdf. Accessed 27 Oct 2020

Pérez de Nanclares JM (2019) La Unión Europea como comunidad de valores: a vueltas con la crisis de la democracia y del Estado de Derecho. Teoría y Realidad Constitucional 43:121-159

Pescatore P (1974) The law of integration. Emergence of a new phenomenon in international relations, based on the experience of the European Communities. A.W. Sijthoff, Leiden 
Pescatore P (1983) The doctrine of direct effect: an infant disease of community law. Eur Law Rev 8:155-177

Pescatore P (2008) La carence du législateur communautaire et le devoir du juge (1983). In: Picod F (ed) Études de droit communautaire européen 1962-2007. Bruylant, Brussels, pp 613-636

Peters A (2000) Elemente einer Theorie der Verfassung Europas. Duncker\&Humblot, Berlin

Pörsken U (2004) Plastic words: the tyranny of a modular language. The Pennsylvania State University Press, Pennsylvania

Potacs M (2016) Wertkonforme Auslegung des Unionsrechts? Europarecht 51:164-176

Prechal S (2017) Mutual trust before the Court of Justice of the European Union. Eur Papers 2:75-92

Rasmussen H (1986) On law and policy in the European Court of Justice. Martinus Nijhoff, Dordrecht

Reding V (2013) The EU and the rule of law - what next? http://europa.eu/rapid/press-release SPEECH-13-677_en.htm. Accessed 27 Oct 2020

Rosas A (2012) When is the EU Charter of fundamental rights applicable at national level? Jurisprudencija/Jurisprudence 19:1269-1288

Rosas A, Armati L (2018) EU constitutional law, 3rd edn. Hart, Oxford

Rossi LS (2020) La valeur juridique des valeurs. L'article 2 TUE: relations avec d'autres dispositions de droit primaire de l'UE et remèdes juridictionnels. Revue trimestrielle de droit européen:639-657

Roth WH (2011) Verfassung und europäische Methodenlehre. Rabel J Comp Int Private Law $75: 787-844$

Safjan M (2014) Fields of application of the Charter of fundamental rights and constitutional dialogues in the European Union, EUI Distinguished Lecture 2014/02

Safjan M, Düsterhaus D, Guérin A (2016) La Charte des droits fondamentaux de l'Union européenne et les ordres juridiques nationaux. Revue trimestrielle de droit européen:219-247

Sarmiento D (2013) Who's afraid of the Charter? The Court of Justice, national courts and the new framework of fundamental rights protection in Europe. Common Market Law Rev 50:1267-1304

Scheppele KL (2016) Enforcing the basic principles of EU law through systemic infringement actions. In: Closa C, Kochenov D (eds) Reinforcing rule of law oversight in the European Union. Cambridge University Press, Cambridge, pp 105-132

Scheppele KL (2018) Autocratic legalism. Univ Chicago Law Rev 85:545

Scheppele KL, Kochenov D, Grabowska-Moroz B (2020) EU values are law, after all: Enforcing EU values through systemic infringement actions by the European Commission and the member states of the European Union. Yearb Eur Law 38 (forthcoming)

Schiffauer P (2019) Ein Anker von Rechtsstaatlichkeit in der Europäischen Union durch den Verbund der Verfassungs- und Obersten Gerichte. Neue Begründungswege in der jüngsten Rechtsprechung des EuGH zur Reform des polnischen Justizsystems. Europäische Grundrechtezeitschrift 46:549-571

Schill S, Krenn C (2020) Art. 4 EUV. In: Grabitz E, Hilf M, Nettesheim M (eds) Das Recht der Europäischen Union. C.H. Beck, Munich

Schmidt M, Bogdanowicz P (2018) The infringement procedure in the rule of law crisis: how to make effective use of Article 258 TFEU. Common Market Law Rev 55:1061-1100

Schorkopf F (2016) Wertesicherung in der Europäischen Union. Prävention, Quarantäne und Aufsicht als Bausteine eines Rechts der Verfassungskrise? Europarecht 51:147-164

Schorkopf F (2020) Value Constitutionalism in the European Union. German Law J 21:956-967

Schroeder W (ed) (2016a) Strengthening the rule of law in Europe. Hart, Oxford

Schroeder W (2016b) The European Union and the rule of law - state of affairs and ways of strengthening. In: Schroeder W (ed) Strengthening the rule of law in Europe. Hart, Oxford, pp 3-34 
Shapiro S (2011) Legality. Harvard University Press, Cambridge

Skouris V (2018) Demokratie und Rechtsstaat. C.H. Beck, München

Somek A (2010) The argument from transnational effects I. Eur Law J 16:315-344

Spaventa E (2016) The interpretation of Article 51 of the EU Charter of fundamental rights. European Parliament, PETI Committee. www.europarl.europa.eu/RegData/etudes/STUD/ 2016/556930/IPOL_STU(2016)556930_EN.pdf. Accessed 27 Oct 2020

Spieker LD (2019a) Breathing life into the Union's common values: on the judicial application of Article 2 TEU in the EU value crisis. German Law J 20:1182-1213

Spieker LD (2019b) Commission v. Poland - a stepping stone towards a strong 'Union of Values'? Verfassungsblog, 30 May 2019

Streinz R (2018) Principles and values in the European Union. In: Hatje A, Tichý L (eds) Liability of member states for the violation of fundamental values. Europarecht Beiheft 1/2018. Nomos, Baden Baden, pp 11-22

Sunstein CR (1999) One case at a time. Judicial minimalism on the Supreme Court. Harvard University Press, Cambridge

Toggenburg GN, Grimheden T (2016) Managing the rule of law in a heterogeneous context: a fundamental rights perspective on ways forward. In: Schroeder W (ed) Strengthening the rule of law in Europe. Hart, Oxford, pp 221-241

Tridimas T (2007) The general principles of EU law, 2nd edn. Oxford University Press, Oxford

Tridimas $\mathrm{T}$ (2011) Constitutional review of member state action: the virtues and vices of an incomplete jurisdiction. ICON 9:737-756

Tridimas T (2013) Bifurcated justice: the dual character of judicial protection in EU law. In: Rosas A, Levits E, Bot Y (eds) The Court of Justice and the construction of Europe. T.M.C. Asser Press, The Hague, pp 367-380

von Bogdandy A (2010) Founding principles. In: Bast J, von Bogdandy A (eds) Principles of European constitutional law, 2nd edn. Hart, Oxford, pp 11-54

von Bogdandy A (2020) Principles of a systemic deficiencies doctrine: how to protect checks and balances in the member states. Common Market Law Rev 57:705-740

von Bogdandy A, Ioannidis M (2014) Systemic deficiency in the rule of law: what it is, what has been done, what can be done. Common Market Law Rev 51:59-96

von Bogdandy A, Spieker LD (2019) Countering the judicial silencing of critics. Article 2 TEU values, Reverse Solange, and the responsibilities of national judges. Eur Const Law Rev 15:391-426

von Bogdandy A et al (2012) Reverse Solange - protecting the essence of fundamental rights against EU member states. Common Market Law Rev 49:489-519

von Bogdandy A et al (2018) Guest editorial: a potential constitutional moment for the European rule of law - the importance of red lines. Common Market Law Rev 55:983-995

von Danwitz T (2018) Values and the rule of law: foundation of the European Union - an inside perspective from the ECJ. Revue du droit de l'Union européenne 4:263-270

Voßkuhle A (2017) The idea of the European community of values. Thyssen Lectures. Bittner, Cologne

Waelbroeck M, Oliver P (2017) La Crise de l'État de Droit dans l'Union Européenne: Que Faire? Cahiers de droit européen 26:299-342

Weiler JHH (2016a) Epilogue: living in a glass house: Europe, democracy and the rule of law. In: Closa C, Kochenov D (eds) Reinforcing rule of law oversight in the European Union. Cambridge University Press, Cambridge, pp 313-326

Weiler JHH (2016b) Taking (Europe's) values seriously. In: Hofmann R, Kadelbach S (eds) Law beyond the state. Campus, Frankfurt, pp 93-150

Wendel M (2019) Mutual trust, essence and federalism - between consolidating and fragmenting the area of freedom, security an justice after LM. Eur Const Law Rev 15:17-47

Williams AT (2009) Taking values seriously: towards a philosophy of EU law. Oxf J Legal Stud 29:549-577 
Wohlfahrt C (2016) Die Vermutung unmittelbarer Wirkung des Unionsrechts. Plädoyer für die Aufgabe der Kriterien hinreichender Genauigkeit und Unbedingtheit. Springer, Heidelberg Zglinski J (2018) The rise of deference: the margin of appreciation and decentralized judicial review in EU free movement law. Common Market Law Rev 55:1341-1385

Luke Dimitrios Spieker is a PhD Candidate and Research Fellow at the Max Planck Institute for Comparative Public Law and International Law, Heidelberg.

Open Access This chapter is licensed under the terms of the Creative Commons Attribution 4.0 International License (http://creativecommons.org/licenses/by/4.0/), which permits use, sharing, adaptation, distribution and reproduction in any medium or format, as long as you give appropriate credit to the original author(s) and the source, provide a link to the Creative Commons license and indicate if changes were made.

The images or other third party material in this chapter are included in the chapter's Creative Commons license, unless indicated otherwise in a credit line to the material. If material is not included in the chapter's Creative Commons license and your intended use is not permitted by statutory regulation or exceeds the permitted use, you will need to obtain permission directly from the copyright holder. 